\title{
AKHLAK ISLAMI PERSPEKTIF ULAMA SALAF
}

\author{
Syamsul Rizal Mz \\ (Institut Ummul Quro Al-Islami Bogor) \\ rijaa.ghoib@gmail.com
}

Received: 06-03-18, Accepted: 01-04-18, Published: 16-04-18

\begin{abstract}
Abstrak
This paper intends to analyze the concept of Islamic morality in the opinion of one of the leaders of the salaf cleric, that is Imam al-Ghazali. One of his phenomenal works is a book of tasawuf containing religious advice that is Ihya 'Ulum al-Din and other books that explain about morals. So, what kind of morals according to him and how the method to be good morals. This is the focus of the problem in this study. The concept of Imam Al-Ghazali's thought can provide reflection to everyone who studies it on how good morals and application should be done by every Muslim individual. The approach used in this research is the library research, or research literature with the type of qualitative research. The source of the data is a few books by Al-Ghazali. The collected data was analyzed by using descriptive method of analysis or content analys. The results of this study, that the moral concepts according to Imam Al-Ghazali include; Understanding morals, the division of various kinds of morals, (Al-Khuluq Al-Hasan) and bad morals (al-Khuluk as-Sayy'i), the method of formation is Mujahadah and Riyadhah (training). One must have a strong determination to want to change and to abandon the excessive lust and Al-Ghazabiyah that exist in the soul, then muhasabah Al-Nafs (introspection), and Istiqomah (continuous). Islamic morality comes from the Qur'an and Hadith.
\end{abstract}

\begin{abstract}
Abstrak
Tulisan ini bermaksud menganalisis konsep akhlak Islami menurut pendapat salah satu tokoh dari ulama salaf, yaitu Imam Al-Ghazali. Salah satu karyanya yang fenomenal adalah sebuah kitab tasawuf yang berisi nasehat-nasehat agama yaitu Ihya 'Ulum al-Din dan kitab lainnya yang menjelaskan mengenai akhlak. Sehingga, seperti apa akhlak menurutnya dan bagaimana metode menjadi akhlak yang baik. Inilah yang menjadi fokus masalah dalam penelitian ini. Konsep pemikiran Imam Al-Ghazali itu dapat memberikan refleksi kepada setiap orang yang mengkajinya tentang bagaimana akhlak dan penerapannya yang baik harus dilakukan oleh setiap individu muslim. Pendekatan yang digunakan dalam penelitian ini adalah library research, atau penelitian kepustakaan dengan jenis penelitian kualitatif. Sumber datanya adalah beberapa kitab karangan Al-Ghazali. Data yang terkumpul dianalisa dengan menggunakan metode deskriptif analisis atau content analys. Hasil penelitian ini, bahwa konsep akhlak menurut Imam Al-Ghazali meliputi; Pengertian akhlak, pembagian macam-macam akhlak, (Al-Khuluq Al-Hasan) dan akhlak yang buruk (Al-Khuluk As-Sayy'i), metode pembentukannya adalah Mujahadah dan Riyadhah (pelatihan). Seseorang harus memiliki tekad yang kuat untuk mau berubah dan meninggalkan nafsu syahwat yang berlebihan dan Al-Ghazabiyah yang ada dalam jiwa, kemudian muhasabah Al-Nafs (introspeksi), dan Istiqomah (kontinu). Akhlak Islami bersumber dari Al-Qur'an dan Hadits.
\end{abstract}

Keywords: morals, salafic scholars, Al-Ghazali. 


\section{A. PENDAHULUAN}

Elemen yang paling penting dalam membangun sebuah peradaban adalah pendidikan. Jika dilihat dari perspektif sejarah, kehidupan umat Islam pernah mengalami pasang surut, dan naik-turun. Umat Islam pernah mengalami masa pertumbuhan, perkembangan, kejayaan. Hal ini dibuktikan dalam sejarah peradaban Islam pada masa dinasti abbasiah dengan adanya Baitul Hikmah sebagai pusat kegiatan intelektual saat itu. Umat Islam juga pernah mengalami kemunduran, akan tetapi mulai akhir abad ke-19 ada gejala-gejala menuju kebangkitan kembali. ${ }^{1}$ Peradaban umat Islam pernah memimpin peradaban dunia tidak kurang 600 tahun (sejak abad 7 M-13 M). namun sejak abad ke-13 M. sampai sekarang peradaban umat Islam mengalami pasang surut. Sementara di wilayah barat saat ini menunjukan diri sebagai peradaban dunia dengan munculnya lembaga-lembaga pendidikan yang terkemuka.

Perkembangan pendidikan juga dapat dilihat dan dirasakan dengan perkembangan teknologi yang telah terbukti membawa perubahan besar pada kehidupan di dunia, terutama di negaranegara barat yang mengaku sebagai pelopor teknologi. Arus globalisasi tersebut, disamping berdampak positif juga membawa dampak negatif yang tidak kalah besar pengaruhnya terhadap cara pandang kehidupan manusia di dunia khususnya di Indonesia.

Di tengah-tengah era globalisasi dan hegemoni peradaban barat saat ini, seyogyanya para ulama dan cendikiawan muslim juga memahami paham-paham yang berasal dari barat yang kini

1 Ahmad Syafi'i Ma'arif. 1997. Islam Kekuatan Doktrin dan Kegamangan Ummat. Yogyakarta: Pustaka Pelajar. hlm. 34-37. menghegemoni pemikiran umat Islam. ${ }^{2}$ Perubahan tersebut dapat dilihat dari hilangnya nilai-nilai leluhur bangsa. Indonesia yang dahulu terkenal ramah, sopan santun dan memiliki rasa toleransi yang tinggi sudah mulai sulit ditemukan saat ini.

Dalam beberapa bulan terakhir, Negara ini disuguhkan banyak sekali tindak kekerasan. Parahnya tindakan itu menyasar kepada simbolsimbol Negara. Mulai dari penyerbuan serta pembakaran Mapolres Ogan komering Ulu (OKU) Sumatra selatan, penyerbuan ke LP seleman, hingga kasus penganiayaan kapolsek Dolok Pardamean, Simalungun, AKP Andar Yonas Siahaan. ${ }^{3}$ Symbol Negara yang seharusnya menjadi pelindung serta menjadi contoh yang baik kepada rakyatnya, sering kali menampakan sikap yang tidak ramah dan selal identik dengan kekerasan yang mengakibatkan kemarahan. Kejadian itu pun dapat dilihat dan diikuti oleh masyarakat yang berpendidikan rendah, terutama rendah dalam pengetahuan agama.

Fenomena ini telah menimbulkan keprihatinan bagi banyak kalangan terutama bagi dunia pendidikan. Kondisi tersebut tidak boleh dibiarkan, apapun alasannya, kasuskasus kekerasan seperti itu wajib diselesaikan dan dicarikan solusinya. Karena kekerasan tersebut terjadi bukan hanya pengaruh globalisasi semata, akan tetapi dampak dari kegagalan sistem pendidikan di negeri ini. ${ }^{4}$ Sebagaimana diketahui, sistem pendidikan di Indonesia memiliki sistem dualisme,

2 DR. Adian Husaini,. 2011. Pendidikan Islam, Memebentuk Manusia Berkarakter dan Beradab”, Jakarta; Komunitas Nuun. hlm, 115 Lihat Detik.com, terkait kasus Penyerbuan serta Pembakaran Mapolres OKU 4 Mansur Muslich, Pendidikan Krakter. 2011. menjawab Tantangan Krisis Multidimensional. Jakarta; PT Bumi Aksara. hlm 2. 
yaitu terdapat pendidikan agama yang berada dibawah Kementrian Agama yang disebut dengan MI, MTS, Aliyah, dan Perguruan Tinggi Islam. Kemudian Pendidikan Umum di bawah Mendikbud, yang membawahi SD, SMP, SMA dan Perguruan Tinggi Negeri. Perbedaan tersebut sangat jelas, terutama dari muatan materi yang diberikan, pendidikan Agama lebih banyak muatan materi keagamaan. Dan pendidikan Umum mengedepankan materi-materi yang umum. Hal itu, selamanya akan berbeda cara pandang di masyarakat ${ }^{5}$.

Siswa yang selesai dari sekolah negeri, akan berbeda cara pandangnya dengan siswa tamatan pesantren atau Aliyah. Selain itu, Indonesia juga merupakan masyarakat yang berkependudukan mayoritas muslim, dan selalu mengusung "Islam adalah Rahmatan Lilalamin", namun masih jauh dari kenyataannya. Dan konsekwensinya ialah segala hal yang berkaitan dengan Indonesia, maka umat Islam masuk di dalamnya.

Perubahan yang mengarah pada perbaikan masyarakat Indonesia harus segera dimulai. Generasi Indonesia saat ini merupakan produk sistem pendidikan warisan penjajah yang nampak meningggalkan nilainilai etika serta karakter beragama. Sekalipun penanaman karakter atau akhlak saat ini sudah dicantumkan dalam Sisdiknas yang tertuang dalam Pendidikan Nasioal ${ }^{6}$. Akan tetapi, belum dapat diaplikasikan dengan maksimal, karena tidak dikembalikan pada akhlak peserta

\footnotetext{
${ }^{5}$ https://www.facebook.com/KomunikasiAn tarGuruIndonesia/posts/1015121000 9741483 lihat juga Yasmadi,M.A, Modernisasi Pesantren, hlm, 3 di Lihat Pada hari ahad tgl 8 bln sept 2013.

${ }^{6}$ http://edukasi.kompasiana.com/2013/04/22 /kurikulum-2013-dari-sisi-pandanguu-no20-th2003-tentang-sisdiknas-553630.html dilihat pada hari ahad tgl 8 bulan pkl 21;30 2013.
}

didik secara langsung. Anak hanya belajar secara teoritis tidak pada aplikatif yang mendorong pembiasaan setiap hari.

Selanjutnya, persoalan iman, takwa, dan akhlak mulia peserta didik di sekolah sepenuhnya diserahkan kepada guru PAI. Konsekwensinya, jika ada salah satu peserta didik yang berbuat tidak sesuai dengan Iman, takwa dan akhlak yang baik, maka yang menjadi sorotan utama adalah guru PAI. ${ }^{7}$ di sisi yang lain, guru mata pelajaran agama tidak mempunyai waktu yang sama seperti mata pelajaran yang lain, yakni mata pelajaran untuk kemampuan intelektual.

Padahal sudah terbukti, bahwa model pendidikan yang hanya menitik beratkan pada kemampuan intelektual tidak dapat mencetak manusia yang unggul segalanya. Dan berdasarkan sumber PERC (Political and Economic Risk Consutancy), menunjukan tingkat korupsi di Indonesia meningkat, bahkan tertinggi di Asia. Hal ini cukup memprihatinkan dengan penduduk mayoritas muslim terbesar di dunia.

Persoalan akhlak harus menjadi perhatian bagi lapisan masyarakat, khususnya lembaga pendidikan Islam yang lebih banyak muatan agama, sehingga diwajibkan untuk selalu menanamkan budi pekerti atau akhlak kepada peserta didik, dan banyak memuat unsur-unsur pendidikan ruhani, pendidikan akal, pendidikan jasmani, pendidikan agama yang meliputi alQur'an, hadits dan muamalah, pendidikan politik serta pendidikan estetika dan jihad. ${ }^{8}$

7 Prof. Dr. H. Sutrisno, M.Ag. 2011.Pembaharuan dan Pengembangan Pendidikan Islam, membentuk insan kamil yang sukses dan berkualitas". Yogyakarta. Fadilatama. hlm. 157.

${ }^{8}$ Prof. H. Maswardi Muhammad Amin. 2011. Pendidikan Karakter Anak Bangsa”. Jakarta ; Baduose Media Jakarta. hlm. 7. 
Akhlak dalam peradaban Islam merupakan pagar yang membatasi sekaligus dasar yang di atasnya kejayaan Islam. Nilai-nilai akhlak dalam Islam masuk dalam setiap aturan kehidupan, baik secara individu maupun masyarakat, politik maupun ekonomi. Bahkan. Rasulullah diutus tak lain hanya untuk menyempurnakan akhlak. Sebagaimana sabdanya, "Sesungguhnya aku diutus untuk meyempurnakan akhlak yang baik" (HR. Imam Malik).

Dan salah satu keberhasilan da'wah Rasulallah Shallallahu 'alaihi wa sallam, adalah dengan akhlak atau budi pekerti yang baik, maka tidak salah jika Michael H. Hart, mencatat Rasulallah Shallallahu 'alaihi wa sallam sebagai orang nomer satu di antara 100 tokoh yang paling berpengaruh di dunia. Menurutnya, salah satu keberhasilan da'wah Rasulullah, ialah dengan memainkan peran terhadap teologi Islam maupun prinsip moral dan etikanya?

Semestinya, akhlak atau budi pekerti yang Rasulallah Saw, contohkan dan ajarkan diikuti oleh manusia pada saat ini, pasalnya, akhlak dan budi pekerti memiliki arti penting secara maknawi atau ruhani dalam peradaban manusia. Peradaban masa lalu sebagaimana telah diketahui sangat menghormati dan mengikuti leluhurnya, sehingga ajaran yang disampaikan tetap dijaga dan dilestarikan. Akhlak yang dibicarakan pada saat itu bukan hanya sebatas teori, namun melekat pada dataran praktek.

Defenisi yang mudah difahami dari akhlak itu adalah adat yang dengan sengaja dikehendaki, dalam arti lain adalah 'azimah atau kemauan yang kuat tentang sesuatu yang dilakukan

\footnotetext{
${ }^{9}$ Michael H. Hart. 2009. 100 Tokoh Paling Berpengaruh di Dunia. terjemahan Ken Ndaru, M. Nurul Islam. Bandung : Noura books. hlm. 7.
}

berulang-ulang sehingga menjadi kebiasaan yang mengarah kepada kebaikan dan keburukan. Para tokoh abad lampau juga menekankan pentingnnya pendidikan akhlak sebagai salah satu landasan dasar dari sebuah proses pembentukan karakter dalam pendidikan ${ }^{10}$. Imam Al-Ghazali misalnya, mengklasifikasikan pendidikan menjadi dua golongan besar, yaitu pendidikan rohani (tauhid) dan pendidikan jasmani, namun pembahasan di dalamnya termasuk pendidikan akhlak. Menurut Al-Ghazali dalam mendefinisikan akhlak sebagai ihwal yang melekat dalam jiwa, lalu timbul perbuatan-perbuatan dengan mudah tanpa dipikir dan diteliti. ${ }^{11}$ Jika hal ihwal atau tingkah laku tersebut menimbulkan perbuatan-perbuatan yang baik lagi terpuji oleh akal dan syara maka tingkah laku itu dinamakan akhlak yang baik, begitu pula sebaliknya, jika menimbulkan perbuatan yang buruk maka tingkah laku itu dinamakan akhlak yang buruk.

Akhlak yang mulia atau budi pekerti yang baik itu merupakan satu di antara sifat seseorang baik pemimpin, para utusan Allah, dan merupakan amal serta perbuatan orang-orang terpercaya (shiddiqun) yang paling utama. Akhlak yang baik sebenarnya menjadi bagian dari esensi agama dan sekaligus juga buah dari kesungguhan orang-orang yang bertakwa, serta pelatihan bagi orang-orang yang ahli dalam urusan ibadah. Sedangkan akhlak yang buruk lebih sebagai racun pembunuh yang membinasakan, memecahkan kepala, melingkari perbuatan-perbuatan yang keji, perbuatan-perbuatan yang kotor, dan kekejian-kekejian lain yang sanggup

${ }^{10}$ Dr. Ulil Amri Syafri, M.A. Pendidikan Krakter Berbasis Al-Qur'an. Jakarta, Rajawali Pers. hlm, 70.

11 Prof, Masdar Helmy. Akhlak Nabi Muhammad SAW, keluhuran dan kemuliaannya. hlm. 15 . 
menjauhkan hamba dari rabb semesta alam, juga yang memasukan orang yang memilikinya kepada jerat atau perangkap syetan. $^{12}$ Menurut tokoh muslim abad 20 Hamka, pendidikan merupakan sarana untuk mendidik watak-watak pribadi dan manusia dilahirkan tidak hanya cukup mengenal antara baik dan buruk saja akan tetapi juga harus beribadah kepada Allah, bermanfaat bagi sesama dan lingkungannya. Dan menurutnya bahwa sistem pendidikan modern sehebat apapun bila tidak diiringi dengan pendidikan agama dan akhlak yang mulia maka itu tidak akan berhasil dengan baik. ${ }^{13}$ Dengan kata lain, pembentukan watak yang baik harus berkesinambungan atau terus menerus agar menjadi akhlak yang baik.

Dari pemaparan di atas, untuk merubah suatu keadaan yang lebih baik harus dilibatkan peran akhlak yang mulia, namun mendefinisikan makna akhlak itu sendiri cakupannya sangatlah luas terutama menurut pemikiran Imam Al-Ghazali, dan hampir disetiap kitab karangannya selalu mencantumkan akhlak yang mulia serta dengan caracara pendekatannya agar mencari manusia yang lebih baik. Di antara karya Al-Ghazali yang paling monumental ialah Ihya Ulum al-Din (menghidupkan kembali Ilmuilmu agama), kitab tersebut berisikan kumpulan pokok-pokok agama dan akidah, ibadah, akhlak, dan kaidahkaidah suluk, adab dan lain sebagainya. Perhatian Al-Ghazali terhadap akhlak bukan hanya faktor sosial atau lingkungan saat itu, akan tetapi akhlak merupakan jalan bagi manusia menuju kehidupan di dunia dan di akhirat.

12 Al-Ghazali,. Ihya al-Ulumuddin, menghidupkan kembali ilmu-ilmu agama. hlm. 170 .

${ }^{13}$ Herry Muhammad, dkk. 2006. Tokohtokoh Islam Abad 20 yang berpengaruh". Jakarta: Gema Insani. hlm. 64.
Berangkat dari masalah tersebut, penulis tertarik untuk menggali lebih dalam konsep akhlak menurut pemikiran Imam Al-Ghazali yang diharapkan menjadi solusi alternatif untuk sebuah perubahan, khususnya perubahan pada manusia untuk menjadi lebih baik yang didukung dengan lembaga pendidikan yang ada saat ini serta untuk kemajuan bangsa pada umumnya.

Berdasarkan uraian di atas, maka penelitian ini dibatasi dengan beberapa masalah, diantaranya; 1) Bagaimana konsep akhlak menurut Imam AlGhazali? 2) Bagaimana metode membentuk akhlak yang baik?

Adapun tujuan penelitian ini yaitu; 1) Untuk mengetahui konsep akhlak menurut Imam Al-Ghazali, 2) Untuk mengetahui proses membentuk akhlak yang baik.

Kegunaan penelitian ini adalah untuk mengetahui dan menemukan jawaban konsep akhlak menurut Imam Al-Ghazali. Rincian kegunaan secara pokok dari masalah di atas yaitu antara lain; 1)Memberikan pemahaman tentang pentingnya akhlak bagi pendidik dan peserta didik disaat lemahnya moralitas., 2) bagi Lembaga Pedidikan Islam sebagai benteng moralitas bangsa bisa tetap konsisten dengan ajaran-ajaran leluhurnya sebagai yang utama, kemudian ditambah dan disesuaikan dengan perkemangan zaman, 3) Bagi penulis kegunaan penelitian ini adalah untuk menambah wawasan keilmuan sebagai bahan pengembangan pembelajaran khususnya terkait pendidikan agam Islam. Selain itu, penelitian ini juga diharapkan bermanfaat secara teoritis, hasilnya bisa menjadi reverensi tambahan bagi pendidik untuk peningkatan karakter peserta didik khususnya pada lembaga Pendidikan Islam. 


\section{B. TINJAUAN PUSTAKA}

\section{Pandangan Akhlak Menurut Imam Al-Ghazali}

\section{a. Pengertian Akhlak}

Akhlak yang baik sebenarnya menjadi bagian dari esensi agama dan sekaligus juga buah dari kesungguhan orang-orang yang bertakwa, serta pelatihan bagi orang-orang yang ahli dalam urusan ibadah mendekatkan diri kepada Allah. Sedangkan akhlak yang buruk lebih sebagai racun pembunuh yang siap membinasakan manusia, menjauhkan manusia dari sisi Allah, serta memasukan manusia yang memilikinya kepada eratan syaitan.

Imam Abu Hamid Muhammad bin Muhammad, atau yang dikenal dengan sebutan Imam Al-Ghazali sebelum memulai pembahasan tentang akhlak, beliau memulai dengan pembahasan alQalb, al-Ruh, al-Nafs dan al-Aql. Lebih jauh dari itu, Al-Ghazali juga membahas tentang manusia, tujuan hidup manusia sebagai individu. Menurutnya manusia dalam hidupnya adalah mencari kebahagiaan dan kebahagiaan yang paling penting adalah di masa yang akan datang yakni kehidupan akhirat. Tujuan kebahagiaan ini dapat dicapai melalui amal baik lahir maupun dzahir, berupa ketaatan kepada ajaran agama mengenai aturan bertingkah laku atau berhubungan dengan sesama manusia serta upaya batiniah untuk mencapai kebaikan dan keutamaan jiwa. Landasan inilah yang menjadi pemikiran imam Al-Ghazali tentang akhlak yang kemudian banyak dituangkan dalam karyanya kitab Ihya ulum al-Din.

Menurut Al-Ghazali dalam menjelaskan kata al-Khalqu (ciptaan, makhluk) dan al-Khuluqu (akhlak) itu adalah dua contoh yang bisa dipergunakan secara bersama-sama dalam satu rangkaian kalimat. Seperti diucapkan, "Pulan itu bagus bentuknya dan juga akhlaknya." Yang dimaksud dengan al-Khalqu merupakan bentuk lahiriah, adapun yang dimaksud dengan al-Khuluqu merupakan bentuk batiniah. Hal itu karena manusia terdiri dari jasad yang dapat dilihat oleh mata, dan juga ruh serta jiwa yang dapat dilihat melalui penglihatan kalbu ${ }^{14}$. Oleh karena itu, kata Khuluqu (akhlak) menurut AlGhazali jika dilihat secara terminology adalah

"Suatu ibarat atau ungkapan
tentang kondisi yang menetap
di dalam jiwa, dari keadaan
dalam jiwa itu kemudian
muncul perbuatan-perbuatan
dengan mudah, tanpa
memerlukan pemikiran maupun
penelitian". Jadi, apabila
aplikasi dari kondisi tersebut
muncul perbuatan-perbuatan
yang baik dan terpuji secara
akal dan syara', maka kondisi
tersebut disebut sebagai akhlak
yang baik. Sedangkan apabila
perbuatan-perbuatan yang
muncul dari kondisi yang
dimaksud adalah sesuatu yang
berdampak buruk, maka
keadaan yang menjadi tempat
munculnya perbuatanperbuatan
itu disebut sebagai akhlak yang
buruk.

Imam Al-Ghazali mendefinisikan akhlak tersebut dengan mengkaji firman Allah S.W.T, yang mengagungkan urusan jiwa dengan disandarkan hanya kepada-Nya.

"Sesungguhnya Aku akan
menciptakan manusia dari
tanah. Apabila telah Aku

${ }^{14}$ Al-Ghazali. Ihya Ulum al-Din. Jilid IV. hlm. 187-188

157 Ibid. 
sempurnakan kejadiannya, dan aku tiupkan kepadanya ruh (ciptaan-Ku, maka hendaklah kalian tersungkur dengan bersujud kepadanya." (QS.Shad [38] : 71-72)

Di dalam ayat tersebut Allah S.W.T, menginggatkan bahwa jasad manusia itu dihubungkan kepada tanah, sedangkan ruh manusia dihungkan langsung kepada Allah, Rabb seru sekalian alam. Yang dimaksudkan dengan ruh dan jiwa pada tempat ini ialah satu. Artinya, Al-Ghazali hendak menyampaikan disini, bahwa semua itu merupakan kondisi yang menetap di dalam jiwa. Karena itu, manusia yang memberikan harta disebabkan adanya satu kebutuhan atau suatu maksud tujuan tertentu, maka hal itu tidak dapat disebut sebagai representasi dari akhlak yang baik atau orang yang pemurah, karena menurut Al-Ghazali hal itu belum menetap menjadi satu di dalam jiwanya secara kuat.

Jadi, hakikat akhlak menurut AlGhazali seperti kondisi jiwa dan bentuknya yang batin. Sebagaimana sempurnya bentuk lahir secara mutlak yang kemudian menjadi tidak sempurna dengan indahnya keberadaan dua mata saja, tanpa hidung, mulut dan pipi, tetapi kebagusan semuanya harus ada agar kebagusan dhahir menjadi sempurna. Maka, demikian pula dalam urusan batiniah (jiwa), ada empat unsur yang harus baik semua, sehingga kebagusan akhlak menjadi sempurna. Apabila kebagusan empat unsur ini seimbang dan setara serta sesuai maka kebagusan akhlak bisa di dapatkan dan niscaya akan mencapai kemuliaannya. Diantara empat unsur tersebut adalah: kekuatan ilmu, kekuatan emosi, kekuatan syahwat, dan kekuatan adil diantara tiga kekuatan tersebut ${ }^{15}$.

\footnotetext{
${ }^{15}$ Ibid. hlm. 189.
}

$\begin{array}{cr}\text { Dengan kekuatan } & \text { ilmu } \\ \text { menurut Al-Ghazali akan } & \text { mudah }\end{array}$ mengetahui perbedaan antara yang jujur dan yang berdusta di dalam setiap perkataan, akan mengetahui antara yang benar dan yang batil dalam beri'tikad dan berbuat. Sehingga setiap perbuatan akan bernilai pahala yang besar, sekali pun amal atau perbuatan itu sedikit.

"Amal yang sedikit akan bermanfaat dengan ilmu dan amal yang banyak tidak akan bermanfaat dengan kebodohan" $"$.

Selanjutnya,

Al-Ghazali menjelaskan hal tersebut dapat diraih hanya dengan ilmu, dan jika kekuatan ilmu itu baik, maka akan mebuahkan hikmah, dan hikmah menurutnya adalah puncak dari akhlak yang baik, hal itu merujuk pada firman Allah :

\section{"Barang siapa yang dikaruniai hikmah, maka sungguh dia telah dikaruniai kebaikan yang banyak." (QS. Al-Baqarah [2]; 269)}

Adapun kekuatan sikap tegas menurut Al-Ghazali terletak pada sikap mampu mengekang dan melepaskannya, menurut batas yang dibutuhkan oleh kebijaksanaan. Demikian pula dengan pengendalian nafsu syahwat. Maka

${ }^{16}$ Ad-Dailami dalam al-Firdaus dari Anas bin Malik. R,a. dijelaskan dari Anas, asbabul Wurud dari hadist ini adalah; ada seorang lakilaki menemui Rasulullah Saw, kemudian ia bertanya : "Ya Rasulallah, amal apa yang paling utama?". Maka Rasulallah menjawab Ilmu pengetahuan tantang Allah. Dikatakannya tiga kali. Lalu orang tersebut bertanya kembali : "ya Rasulallah yang aku tanyakan adalah amal tetapi yang engkau jawab adalah ilmu" kemudian Rasulallah bersabda : "Amal yang sedikit tetapi disertai dengan Ilmu Pengetahuan akan sangat bermanfaat dan amal yang banyak tidak akan bermanfaat dengan kebodohan". Ibnu Hamzah al-Husaini al-Hanafi ad-Damsyiqi. Asbab alWurud, Tarjih. Zafrullah Salim. Jakarta, Kalam mulia. 2005. hlm, 77. 
kebaikannya pula apabila berada di bawah isyarat kebijaksanaan, yakni isyarat akal dan perintah syari'at. Sedangkan kekuatan keadilan (keseimbangan), maka itu merupakan batasan nafsu syahwat dan sikap marah yang berada di bawah isyarat akal dan perintah syari'at. Perumpamaan akal seperti orang yang memberi nasihat atau yang menunjukan jalan pilihan. Sedangkan kekuatan keadilan lebih sebagai suatu kekuasaan. Perumpamaannya adalah seperti orang yang melaksanakan kebaikan atau yang meneruskan isyarat akal demi melakukan kebaikan. Al-Ghazali memberikan perumpamaan seperti seekor anjing buruan yang diajak mengawal binatang buruan, anjing tersebut memerlukan didikan, sehingga lari dan berhentinya harus sesuai dengan isyarat si pemiliknya, tidak menuruti kehebatan nafsu syahwat atau keinginan kuat si anjing itu sendiri. Didikan itu menurut penulis harus berisfat kintinu atau istiqomah serta diringi dengan bimbingan setiap saat sehingga sifat syahwat yang liar dapat mudah dikendalikan dengan selalu mendapat arahan.

\section{b. Pembagian Akhlak}

Setelah merujuk definisi akhlak yang telah dijelaskan panjang lebar di atas, selanjutnya Imam Al-Ghazali membagi akhlak menjadi dua bagian, diantaranya :

\section{1) Akhlak yang baik (Khuluq al- Hasan)}

Menurut Imam al Ghazali dalam menjelaskan pengertian akhlak yang baik, dia menyimpulkan tentang makna akhlak yang baik dengan, " $f a$ manistawat fîhi hâdzihil khishâl wa-'tadalat fa huwa husnul khuluqi muthlaqan. Sebaliknya, bila kekuatan-kekutan itu tidak seimbang maka itulah makna akhlak yang buruk ${ }^{17}$. Al-Ghazali juga mengutip perkataan Sayyidin Ali bin Abi Thalib ra. Yang pernah mengatakan tentang akhlak yang baik " hakikat dari akhlak yang baik dan mulia ialah ada pada tiga perkara; yaitu. Menjauhi larangan Allah S.W.T., mencari yang halal dan berlapang dada kepada sesama manusia. Beliau juga mengutip ucapan Abu Sa'id al-Karaz yang mendefinisikan tentang akhlak yang baik, ia mengatakan; "Hakikat akhlak yang baik ialah, bila mana tidak ada suatu keinginan pun bagi seorang hamba selain hanya bergantung kepada Allah S.W.T.

Menurut penulis kutipan-kutipan AlGhazali mengenai definisi akhlak yang baik selalu melekat dan erat kaitannya dengan Allah S.W.T. Sehingga untuk mencapai akhlak yang mulia hanya dapat diraih dengan selalu menjauhi segala larangannya dan menjalankan segala perintahnya dan hal itu tidak mudah didapat kecuali dengan karakter yang ia telah sebutkan terutama adalah ilmu yang akan mendatangkan hikmah. Artinya standarisasi yang merupaka ciri akhlak yang baik adalah sebuah pengendalian dalam menahan, mengatur serta mendidik agar tidak berlebihan, titik tengah (tashuth) antara yang berlebihan dan sesuatu yang sangat kurang. Seperti sifat dermawan merupakan upaya mendekatkan diri kepada Allah, hal itu juga merupakan akhlak yang mulia atau terpuji, dan perbuatan tersebut berada ditengahtengah diantara sifat kikir dan mubadzir (berlebih-lebihan). Sebagaimana Allah S.W.T. berfirman yang tercantum dalam surat al-Furqon ayat 67.

2) Akhlak yang Buruk (Khuluq alSayyi')

Mengenai akhlak yang buruk (Khuluq al-Sayyi'), menurut Al Ghazali

$$
{ }^{17} \text { Ibid. }
$$


merupakan kebalikan atau lawan dari perbuatan bila mana kekuatan-kekuatan yang ada pada manusia tidak seimbang. Jadi, menurut Al-Ghazali jika kekuatan emosi terlalu berlebihan dalam arti tidak dapat dikendalikan dan cendrung liar, maka hal itu disebut Tahawwur, semberono, nekat atau berani tanpa ada perhitungan tanpa pemikiran yang matang Dan jika kekuatan sikap tegas cendrung kepada menutupi kelemahan atau kekurangan, maka disebut sebagai penakut dan lemah melaksanakan dari apa yang harusnya dikerjakan. Apabila kekuatan syahwat cendrung terlalu berlebihan maka akan muncul sifat rakus (Syarah). Dan, apabila sifat itu cendrung kepada kekurangan tidak stabil, maka hal itu disebut dengan suatu kejumudan, stagnan, tidak berkembang.

Sifat-sifat tersebut menurut AlGhazali tidak pada posisi yang baik, cendrung lemah dan mudah terpengaruh pada sifat malas, sehingga mudah menimbulkan sifat negatif. Dengan demikian, menurut Al-Ghazali yang terpuji dan baik adalah berada pada porsi di tengah-tengah, hal itulah menjadi sebuah keutamaan. Menurut penulis setiap manusia memiliki syahwat atau nafsu, seperti nafsu makan, minum dan lain-lain, dan yang demikian itu adalah normal pada setiap manusia. Namun manusia dianjurkan untuk tidak berlebihan atau rakus dengan menuruti segala kemauan syahwatnya. Sebagaimana Allah berfirman :

\section{"Makan dan minumlah, dan jangan berlebihan, sesungguhnya Allah tidak menyukai orang-orang yang berlebihan" (QS. Al-A'araf : 31).}

Dan ukuran keseimbangan atau pertengahan (mi'yârul I'tidâl) adalah akal dan syariat, (wa mi'yârul I'tidâl huwal 'aqlu wasy syar'u ${ }^{18}$ ). dengan demikian, Al-Ghazali mengambil kesimpulan bahwa landasan akhlak yang baik itu jika sesuai dengan pokok-pokok yang terdiri atas empat prinsip, diantaranya : hikmah (kebijaksanaan), asy-Syaja'ah (keberanian), al-Iffah (menjaga kehormatan diri), dan al-'adl (bersikap adil).

\section{c. Prinsip Keutamaan Akhlak}

Prinsip atau dasar dari keutamaan akhlak pada dasarnya banyak jenisnya, namun Al-Ghazali mengklasifikasikan jenis tersebut dengan empat prinsip yang dianggap sebagai dasar yang dapat mencakup segala aspek, yaitu : a. alHikmah (Kebijaksanaan). b. as-Syaja'ah (Keberanian). c. al-Iffah (Menjaga Kehormatan Diri). d. al-Adl

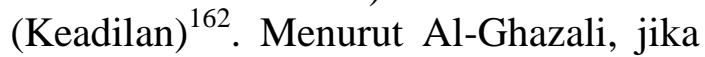
ke empat dasar ini bisa dimunculkan, maka akan lahirlah akhlak yang baik dari semua lapisannya.

\section{1) Al-Hikmah (Bijaksana)}

Menurut Al-Ghazali, yang dimaksud dengan hikamh di dalam karyanya Ihya Ulum al-Din adalah suatu keadaan jiwa yang dapat dipergunakan untuk mengatur sikap marah, dan mengendalikan nafsu syahwat, serta mendorongnya menurut kehendak hikmah. Sedangkan pemakaian dan pengendaliannya dapat diatur juga sesuai dengan kehendak hikmah. Dengan kata lain, kebijaksanaan adalah kondisi jiwa yang memahami yang benar dari yang salah pada semua prilaku yang bersifat ikhtiar/pilihan. Selanjutnya ia juga menyebutkan bahwa hikmah atau kebijaksanaan merupakan salah satu keutamaan jiwa rasional (al-Aqliyah) yang dapat memelihara jiwa serta

${ }^{18}$ Abu Hamid Muhammad bin Muhammad Al-Ghazali. 1986 M. Mizan al-amal. Taqdim, Sulaiman sulaim al-Bawwab. daarul Hikmah. Bairut. hlm. 60 . 
memungkinkan seseorang dapat membedakan yang benar dari yang salah dalam semua perbuatan yang disengaja

Selain itu, ia juga memberi pengertian bahwa hikmah ini merupakan posisi tengah-tengah antara penipu yang pandai dengan kebodohan (al-Baladah). Kelihayan atau kepandaian (al-Khib) merupaka ekstrim kelebihan (ifrath/exess) sedangkan al-Baladah adalah sebagai ekstrim kekurangan (tafrith/deficiency), dan Al-Ghazali menyebut jenisjenis keutamaan yang berada di bawah kebijaksanaan ini adalah dengan pemikiran yang baik Husn al-Tadbir, pemikiran yang jernih Judat al-Zihn, pendapat yang cemerlang Saqabat al-Ra'y, Praduga yang benar atau Ishabat al-Zann, dan selalu sadar terhadap perbuatan kejahatan jiwa yang sangat kecil sekalipun al-Tafathun li Daqa'id al-'Amal wa Khafaya Afat alNufus ${ }^{19}$. Hikamh itulah yang disandarkan pada kekuatan akal yang dapat mengalahkan kekuatan yang ada pada ilmu Dharariah (tanpa berdasarkan akal) atau pun ilmu Nadzhariah (ilmu yang berdasarkan pemikiran dan memerlukan dalil), serta kekuatan yang menguasai tubuh dan segala pengaturannya, sehingga jiwa dapat menemukan kebaikankebaikan amal perbuatan. Kekuatan tersebut bisa disebut dengan akal amaliah.

Kemudian yang kedua disebut "hikmah Khulukiyah". Al-Ghazali mendefinisikan Hikmah Khulukiyah dengan " suatu tingkah dan keutamaan jiwa yang berakal, dan dengan jiwa tersebut dapat mengatur kekuatan marah dan kekuatan syahwat serta dapat membatasi pergerakannya sesuai dengan kadar yang wajib dalam keadaan duka

${ }^{19}$ Ibid, hlm 53. Jika di dalam kitab. Mizan al-'Amal. Hlm. 274, hanya menyebutkan empat tanpa menyebutkan yang terakhir. dan gembira ${ }^{20}$. Dari situ penulis dapat mengambil kesimpulan maksud alhikmah menurut Al-Ghazali, yaitu. Kemampuan sesoarng menggunakan penalaran, renungan dengan benar untuk mendapatkan pengetahuan yang masuk akal/rasional dan kemuadian diaplikasikan setiap hari dalam tingkah lakunya.

\section{2) Ass-Syaja'ah (Keberanian)}

Akhlak yag bertalian dengan sikap keberanian, maka akan dapat menimbulkan sifat pemurah, tegas, keinginan pada hal-hal yang mengharuskan atas perbaikan diri kedepan, mengekang hawa nafsu, menanggung penderitaan, penyantun, berpendirian teguh, menahan sikap kasar, berhati yang tenang dan mulia, bercinta kasih, dan lain sebagainya. Dan rangkaian itu semua merupakan akhlak yang terpuji ${ }^{21}$.

Keberanian itu menurut Al-Ghazali tidak boleh berlebihan, dan jika berlebihan dinamakan tahawwur yakni berani tanpa perhitungan dan pemikiran yang matang, semberono atau nekat. Hal itu, akan menimbulkan sifat-sifat seperti sombong, cepat marah, takabur dan ujub $^{22}$.

Keberanian atau as-Syaja'ah menurut Al-Ghazali juga merupakan suatu keutamaan bagi kekuatan marah, karena memang kekuatan marah itu nyata adanya, namun bersama kekuatan semangatnya, ia harus tunduk kepada akal yang mendapat didikan dengan pendidikan agama dalam tindakan maju dan mundurnya ${ }^{23}$ Dengan demikian, keberanian juga merupakan tindakan

20 Al-Ghazali. Timbangan 'Amal. diedit oleh M. Ali Chasan Umar. hlm. 92.

${ }^{21}$ Abu Hamid Muhammad bin Muhammad Al-Ghazali. “Ihya Ulum al-Din”. Hlm. 192.

${ }^{22}$ Ibid.

${ }^{23}$ Al-Ghazali. Mizan al- 'Amal. Ibid, hlm. 94. 
pertengahan antara kedua kehinaan yang meliputinya yaitu melampui batas dan pengecut, karena sifat pengecut adalah tindakan yang berada pada tingkatan kekurangan, yaitu suatu tindakan yang membawa kurangnya nafsu marah sesuai ukuran yang mesti, sehingga akan menyimpangkan tindakan untuk maju, padahal keadaannya harus maju ${ }^{24}$.

Kesadaran untuk memperoleh konsekwensi keberanian, Al-Ghazali lebih menitik beratkan kepada akibat setelah kematian disbanding dengan semasa masih hidup. Hal ini dapat dimengerti karena sikap yang lebih daminan ada pada pribadinya, sehingga ia lebih cendrung mengutamakan sesuatu hal yang bersifat ukhrawi dari pada halhal yang mengandung unsur duniawi. Sehingga dalam memperjuangkan atau menegakkan suatu keberanian tidak muncul rasa takut mati, sebab itu menurut Al-Ghazali sikap keberanian adalah merupakan salah satu keutamaan akhlak yang amat mulia dan terpuji ${ }^{25}$.

Secara garis besar, yang dibutuhkan pada sikap as-Syaja'ah adalah sebuah pengendalian, di mana seseorang harus pandai memposisikan sikap tersebut berada di tengah-tengah antara sikap berlebih-lebihan dan sikap berkekurangan. Seperti apabila seseorang membiarkan sikap tahawwur (berani tanpa perhitungan, dan pemikiran yang matang, semberono atau nekat) tumbuh di dalam jiwanya tanpa diimbangi dengan memiliki sikap penakut. Maka, akan muncul akhlak yang buruk, sombong, hilang rasa malu, dan bertindak tanpa mempertimbangkan kerugian orang lain. Dari itu, kekuatan, arahan dan pemahaman akal sangat dibutuhkan sebagai penyeimbang dari sikap keberanian. Artinya, manakala terdapat pada diri seseorang sebuah kekuatan, maka dengan kekuatan yang tersedia itu ia akan patuh pada arahan dari pemahaman akalnya. Karena itulah Allah Swt, telah berfirman dalam alqur'an surat Al-Fath ayat 29.

Dalam ayat itu, Allah Swt, memberikan sifat untuk Rasulallah dan para sahabat dengan bersifat tegas, karena sesungguhnya bersikap tegas itu muncul dari landasan sikap tidak menyukai perbuatan aniaya, perbuatan yang dzholim. Namun, jika sikap tegas dan berani itu kemudian hilang, maka niscaya akan hilang pula perjuangan untuk membela dan menegakkan agama ini $^{26}$.

Seperti halnya sikap kebijaksanaan, keberanian juga memiliki beberapa cabang sebagai pendukungnya. AlGhazali menyebut cabangcabang keberanian ini dengan beberapa jenis. Di dalam kitab Mizal al'Amal ia menyebut ada Sembilan macam, berbeda dengan kitab al-Arba'in, Al-Ghazali hanya menyebutkan delapan macam, sedangkan dalam kitab Ihya Ulum alDin, ia menyebutkan ada sepuluh macam cabang dari sifat keberanian. Cabangcabang dari sikap keberanian tersebut adalah: al-Karam (Kemuliaan), alNajdat (Pantang takut), alSyahamat (perkasa), Kibar al-Nafs (Berjiwa besar), al-Ihtimal (tahan uji), al-Hilm (murah hati), al-Sabat (Ulet), Kazhm al-Ghaizh (tahan marah), alWaqar (tahu diri), dan al-Tawaddud (ramah) ${ }^{27}$.

${ }^{26}$ Al-Ghazali, Al-Ghazali. Ihya Ulum alDin. hlm. 199.

${ }^{27}$ Ibid, juz III. Hlm, 53 dan "Mizan al‘Amal”, hlm. 276. 


\section{d. Dasar dan Tujuan Akhlak}

Menurut al-Ghazalai tujuan akhlak yang telah diuraikannya adalah terbentuknya suatu sikap batin yang mendorong munculnya keutamaan jiwa, dan biasa disebut Al-Ghazali dengan alSa'adat al-Haqiqiyat (kebahagiaan yang hakiki) ${ }^{28}$. Dikatakan sebagai kebahagiaan yang hakiki karena, karena akhlak merupakan pusat yang menjadi dasar penilaian keutamaan pada manusia. Dan keuatamaan jiwa menjadi salah satu jalan ketenangan batin manusia sehingga tercapai tujuan hidup yang sebenarnya. kemudian yang menjadi landasan atau konsep akhlak yang dipaparkan AlGhazali adalah alQuran dan al-Hadist. Ia juga menjelaskan seputar ayat dan hadits yang menjadi pembimbing akhlak yang mulia. Di antaranya ${ }^{29}$

"Mereka itulah orang-orang yang bertaubat, yang beribadah, yang memuji, yang melawat ${ }^{30}$, yang ruku', yang sujud, yang menyuruh berbuat ma'ruf, dan mencegah dari berbuat munkar, juga yang memelihara hukum-hukum Allah. Dan berikanlah kabar gembira bagi orang-orang yang mukmin (beriman). (QS alTaubah [9] : 112)

"Sungguh beruntunglah orang-oarng yang beriman. Yaitu, orangorang yang khusyu dalam sholatnya, dan orang-rang yang menjauhkan diri dari perbuatan serta perkataan yang tidak berguna. Juga orang-orang

28 Al-Ghazali. 1964. Mizan al-'Amal. Sulaiman Dunya. Kairo: Dar al-Ma'arif. hlm. 303.

29 Al-Ghazali. Ihya Ulum al-Din. terjemah, Ibnu Ibrahim Ba'adillah. Hlm. 247251.

${ }^{30}$ Melawat maknanya untuk mencari ilmu pengetahuan, atau berjihad. Ada pula yang menafsirkan dengan orang-orang yang selalu berpuasa sunnah. yang mau menunaikan zakat, dan orang-orang yang mau menjaga kemaluannya, kecuali trhadap istriistri, atau budak-budak yang mereka miliki, maka sesungguhnya mereka dalam hal ini tidak tercela. Siapa saja yang mencari di balik itu semua, maka mereka itulah orang-orang yang melampaui batas. Dan orangorang yang memlihara amanahamanah (yang dipikulnya), serta memenuhi janjinya, juga orangorang yang menjaga sholatnya. Mereka itulah yang akan mewarisi. (QS al-Mu'minun [23] : 1-10)

"Sesungguhnya orang-orang yang beriman itu adalah mereka yang apabila disebut nama Allah, maka bergetarlah qalbu mereka, dan apabila dibacakan kepada mereka ayat-ayatnya, bertambahlah keimanan mereka, serta kepada Rabblah mereka bertawakal. [yaitu], orang-orang yang mendirikan sholat, dan yang menafkahkan sebagian dari rezki yang kami berikan kepada mereka. Itulah orang-orang yang beriman dengan sebenarbenarnya," (QS al-Anfal [8] : 2-4)

Al-Ghazali juga mengambil beberapa sumber dari al-Hadits yang menunjukan pada akhlak yang baik. Di $\operatorname{antaranya}^{31}$ :

"Seorang mukmin itu mencintai saudaranya, seperti ia mencintai dirinya sendiri." (HR. Bukhari dan Muslim)

"Siapa saja yang menyatakan diri beriman kepada Allah, dan hari akhir, maka berkatalah yang baik, atau diam.” (HR. Muttafaqun 'Alaih)

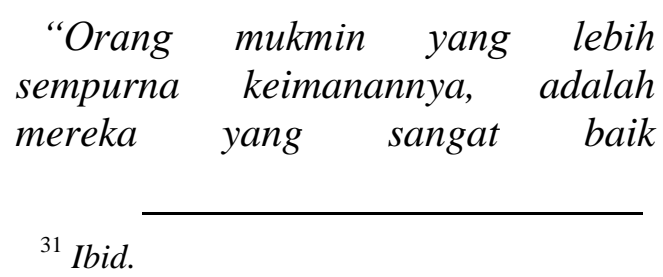


akhlaknya. $^{32}$ " (HR. Abu Hurairah, ra).

"Tidak halal (tidak
diperbolehkan) bagi seorang
muslim untuk menakutnakuti
saudaranya sesame Muslim."
(HR. Imam al-Thabrani)

Selanjutnya , tujuan pendidikan akhlak menurut Al-Ghazali adalah proses manusia untuk mendekatkan diri kepada Allah Swt, selain itu juga sebagai tujuan akhir yang akan dicapai oleh manusia. Membersihkan diri (tazkiyatun an-Nafs), terbiasa selalu berbuat kebaikan dengan akhlak yang kaamil (sempurna), ma'rifah, dengan kata lain ia selalu mendekatkan diri kepada Allah Swt, untuk mendapatkan kebahagiaan dan ketenangan di dunia dan kahirat ${ }^{33}$.

Dengan demikian, pendidikan akhlak adalah suatu upaya pembentukan manusia untuk menjadi lebih sempurna, baik di dunia maupun di akhirat. Menurut Al-Ghazali manusia dapat mencapai paripurna apabila diiringi dengan usaha mencari ilmu dan kemudian mengamalkan fadilah dengan ilmu pengetahuan yang telah ia pelajari. Dengan fadilah ini kembudian diharapkan dapat menjadikan manusia kian dekat kepada Allah Swt, yang kemudian memberikan kebahagiaan hidupnya di dunia dan di akhirat ${ }^{34}$.

Menurut penulis, pendapat AlGhazali dalam mendidik akhlak anak dengan dilatih untuk selalu mendekatkan diri kepada Allah Swt, agar tidak muncul sifat-sifat yang buruk, yang muncul

${ }^{32}$ Hadits berstatus shahih, sebagai mana telah disebutkan oleh Imam al-Bani dalam kitab "shahih al-Jami", hadits nomer 1230, dari riwayat Abu Hurairah ra.

${ }^{33}$ Al-Ghazali. Ihya ulum al-Din. Jilid I, hlm. 50.

34 Djamluddin. 1988. Kapita Selekta Pendidikan Islam. Bandung : Pustaka Setia. hlm 14. dalam hati. Seperti ria, sombong, bukan dengan niat untuk saling menjatuhkan atau pun untuk kemewahan. Dan jika sifat-sifat penyakit hati tidak muncul dengan cara pensucian jiwa dan dekat kepada Allah, maka tujuan pendidikan yang lainnya akan mudah diikuti dan mudah di dapati terutama akhlak yang terpuji.

\section{e. Metode atau Proses Mendidik Akhlak}

Setelah mengetahui tentang akhlak, yang baik dan yang buruk menurut $\mathrm{Abu}$ Hamid Muhammad bin Muhammad AlGhazali. Dan telah mengetahui bahwa akhlak yang baik itu kembali kepada lurusnya kekuatan akal serta sempurnanya hikmah. Juga dengan lurusnya kekuatan mengendalikan nafsu amarah beserta syahwat. Kesemuanya itu pun tunduk pada benarnya kekuatan fungsi akal dan ketaatan terhadap syari'at.

Manusia dengan karunia Allah Swt, diciptakan dan dilahirkan dengan sempurna akalnya dan berakhlak mulia. Allah Swt, pula yang menyimpan peranti lunak di dalam dirinya berupa penguasaan atas nafsu syahwat dan sikap amarah. Bahkan menurut Al-Ghazali syahwat dan sifat marah tersebut diciptakan tunduk kepada fungsi akal dan aturan syari' ${ }^{35}{ }^{35}$. Sekalipun manusia telah dikarunia akal yang sempurna yang menjadi sarana untuk berfikir dan merenung tentang hidup di dunia, akan tetapi, diantara sebagian manusia masih ada yang memperturutkan hawa nafsunya secara berlebihan sehingga menjadi tersendat dan sulit untuk menerima kebenaran dan dan nasehat yang baik.

\footnotetext{
${ }^{35}$ Al-Ghazali. Ihya Ulum al-Din. hlm. 195.
} 
Tingkah laku manusia juga terkadang jauh lebih hina dari pada hewan. Hal itu tidak dapat dipungkiri oleh siapa pun, dan tak terkecuali oleh al-Gahzali. Pasalnya, manusia di dunia adalah sebagai hkalifah yang mengatur kelangsungan hidup di dunia, selanjutnya objek utama pada akhlak

\section{METODE PEMBAHASAN}

Penelitian ini termasuk jenis penelitian kepustakaan (library research), yaitu penelitian yang mengumpulkan seluruh data dan informasi yang terdapat dalam kepustakaan (buku). ${ }^{36}$ Penelitian ini disebut juga dengan penelitian kualitatif, oleh karena itu metode yang digunakan adalah kualitatif dengan menggunakan teknik penulisan deskriptif. ${ }^{37}$

Penelitian ini menggunakan pendekatan histori dari seorang tokoh muslim yang tercatat namanya di era keemasan peradaban Islam. Pendekatan histori berarti banyak meneliti dan mengkaji keadaan-keadaan, pengalaman hidup dan masa belajar serta mengkaji teori-teori, serta menimbang dengan cukup teliti dan hati-hati terhadap bukti validitas dari sumber sejarah. Pendekatan ini digunakan untuk mengatahui sejarah yang berkaitan dengan pemikiran Imam Al-Ghazali tentang konsep akhlak, untuk dapat diketahui sumber dan faktor apa saja yang melahirkan pemikirannya.

Sumber penelitian yang akan digunakan ialah dengan mengumpulkan data-data yang mendukung penelitian. Mengingat penelitian ini bersifat kepustakaan, maka dapat dikelompokan menjadi dua sumber data yaitu, sumber

\footnotetext{
36 Suharsimi Arikunto. Managemen Penelitian. hlm. 332.

${ }^{37}$ Ibid. hlm. 310.
}

juga ada pada manusia. Di mana baik dan buruknya suatu lingkungan juga ditentukan terhadap manusia yang menempatinya. Oleh karena itu, AlGhazali membagi manusia dalam merubah akhlak menjadi baik atau mendidik akhlak yang baik menjadi pada empat tingkatan. Yaitu ${ }^{201}$ :

data primer dan sumber data skunder. Adapun sumber data primer yang akan digunakan pada penelitian ini adalah buku-buku atau karya-karya yang langsung ditulis oleh Al-Ghazali, diantaranya ; Ihya al-Ulumuddin, Minhajul 'abidin, Mizan alAmal, Ayat al-Walad al-Muhib. Sedangkan sumber data skunder adalah semua data yang mendukung dan berkaitan dengan penelitian ini.

Agar penlitian ini terarah secara sistematis, maka diperlukan langkahlangkah yang memudahkan penelitian, dengan cara mengumpulkan data yang relevan, kemudian data-data tersebut dianalisis dengan menggunakan metode deskriptif analisis. Metode itu akan digunakan untuk menjelaskan pemikiran akhlak menurut imam Al-Ghazali, kemudian dianalisa secara umum mengenai rumusan konsep dan karakteristiknya serta relevansinya dengan pendidikan saat ini.

\section{HASIL PEMBAHASAN}

\section{Isi Hasil}

Menurut penulis, sifat berani sangat diperlukan bagi setiap muslim laki-laki dan perempuan, namun bukan hanya harus terukur dan tidak berlebihan, sebagaimana menurut Al-Ghazali. Akan tetapi harus pula disertai dengan memelihara adab atau etika. Pasalnya, sifat tersebut merupakan fondasi terpenting dalam Islam, dan merupakan bentuk dari amar ma'ruf nahi munkar (memerintahkan kebaikan dan mencegah 
keburukan). Sifat tersebut jelas dibutuhkan untuk memerangi kebatilan, penyelewengan yang dilakukan sebagian orang, serta berbagai macam kedzoliman, hal itu juga merupakan sebuah perjuangan dalam menegakkan kebenaran. Al-Qur'an pun telah mengisyaratkan sifat-sifat berani ini, hingga seorang muslim tidak takut mengatakan kebenaran dan tidak pula takut dengan celaan orang lain. Hal ini sebagaimana tercantum dalam surat AlMaidah ayat 54.

Serta Rasulallah Saw, pun bersabda :

\section{"Hendaklah seorang di antara kalian tidak takut karena manusia untuk mengatakan kebenaran jika ia melihatnya, atau menjadi saksinya, karena sesungguhnya dia tidak dekat dari ajal, dan tak jauh dari rezeki disebabkan mengatakan kebenaran atau menjadi saksi itu. "38}

\section{3) Al-'Iffah (Menjaga Kesucian Diri)}

Termasuk ciri pribadi muslim yang baik adalah menjada kehormatan diri (Iffah). Seorang muslim harus selalu berusaha untuk menjaga, mulai dari dirinya, agama, harta, kehormatan serta kemuliannya.

Di dalam al-Qur'an Allah telah menjelaskan kepada orang-orang yang tidak kuasa menjaga kehormatannya dengan menikah untuk selalu menjaga kehormatan.

Katakanlah kepada orang lakilaki yang beriman: "Hendaklah mereka menahan pandanganya, dan memelihara kemaluannya;

38 Ahmad Umar Hasyim. 2004. Menjadi Muslim Kaffah: Berdasarkan al-Qur'an dan Sunnah Nabi. Yogyakarta. Mitra Pustaka. hlm. 157. yang demikian itu adalah lebih suci bagi mereka, Sesungguhnya Allah Maha mengetahui apa yang mereka perbuat. Dan Katakanlah kepada wanita yang beriman: "Hendaklah mereka menahan pandangannya, dan kemaluannya. (QS. An-Nur: 30, 31)

Pembentukan keperibadian yang lurus, tidak akan sempurna tandatandanya kecuali dengan pembersihan jiwa. Yaitu pembersihan lubuk hati manusia yang paling dalam. Pensucian itu harus dilakukan sebelum tandatanda yang nampak dari luar. Jika sesorang tidak mampu mensucikan jiwa, niscaya ia tak mampu melakukan sesuatu yang baik dengan kesenangan hati, dan tidak pula mampu melakukan hal yang sama pada orang lain, dan tidak mampu pula mempengaruhi orang lain untuk menjadi baik.

Jiwa-jiwa yang suci tidak akan muncul dari lingkungan yang tidak baik. Dengan kata lain, munculnya jiwa-jiwa suci dari lingkungan yang Islami dan taat pada syari'at Allah Swt ${ }^{39}$. Mana kala nurani keagamaan telah tumbuh, kesadaran berbuat baik pun akan muncul, manusia akan takut kepada Tuhannya, dan ketika itu juga, jiwa akan melarang untuk melakukan kejahatan dan kemungkaran.

Al'iffah, (memelihara diri agar terhindar dari segala perbuatan tercela $)^{40}$ adalah keutamaan kekuatan syahwat bahimiyah, yaitu kekuatan syahwat yang sangat mudah untuk mengikuti kekuatan akal, sehingga kesedihan dan

\footnotetext{
${ }^{39}$ Ibid, hlm. 206

${ }^{40}$ Al-Ghazali. Ihya 'Ulum al-Din, OP-Cit.
} Juz III, hlm. 53 Istilah Kibar al-nafs dan alihtimal tidak disebutkan dalam "Kitab alArba'in, Loc-Cit.", selanjutnya yang tidak disebutkan dalam "Mizan al- 'Amal adalah kahzm al-ghaizh dan tawaddud”, Op-Cit. hlm. 276. 
kegembiraan sesuai dengan petunjuk yang diperintahkan oleh akal.

$A l$-'iffah diselubungi oleh dua macam budi pekerti tercela, yaitu "keterlaluan syahwat" dan "kelemahan syahwat" yang dimaksud dengan keterlaluan syahwat adalah semangat yang menggebu-gebu untuk mendapatkan kelezatan, kemewahan, kesenangan, yang dianggap buruk oleh kekuatan akal dan akal berupaya untuk mencegahnya. Sementara kelemahan syahwat ialah upaya untuk bangkit setelah mencapai sesuatu yang diinginkan oleh akal. Kedua sifat tersebut tercela, maka untuk menetralisir kedua sifat tersebut diperlukan 'iffah untuk menyeimbangkannya sehingga menjadi sifat yang terpuji.

Manusia berkewajiban untuk mengawasi syahwatnya, biasanya orang cenderung untuk memperturutkan syahwatnya, terutama yang menyangkut alat kelamin, dan perut dan juga kehendak untuk mendapatkan harta yang banyak, pangkat dan kedudukan yang tinggi dan dibarengi dengan gila hormat. Keterlaluan dan kekurangan dalam sifatsifat tersebut adalah merupakan cacat dan merupakan suatu kekurangan, sedangkan yang sempurna adalah keseimbangan menurut ukuran akal yang sehat dan agama yang benar. ${ }^{41}$

Syahwat atau keinginan nafsu dan marah mempunyai peranan yang amat vital dalam kelanggengan manusia dan makhluk lainnya seperti binatang. Sebagai contoh, misalnya rasa lapar akan menggerakan keinginan untuk makan, makanan tentunya harus diupayakan dengan berusaha, dengan makan yang layak dan bergizi maka kebutuhan tubuh akan terpenuhi, ketika kesehatan tubuh dapat dipertahankan, kelangsungan

\footnotetext{
${ }^{41} \mathrm{Ibid}$
}

hidup terus berlanjut serta pancaindra dapat berfungsi dengan sempurna.

Dengan kondisi jasmani yang sehat diharapkan dapat pula meningkatkan kondisi rohani yang baik dengan menuntut ilmu pengetahuan, sehingga manusia dapat menyerupai makhluk yang berbudi luhur seperti malaikat, sehingga dengan tercapainya derajat tersebut, maka tercapai pula kesempurnaan hidup dan kebahagiaan. Apabila manusia telah mengetahui proses dan tujuan pemenuhan kebutuhan hidup seperti makan yang disebutkan di atas, maka tujuan makan tersebut adalah untuk menguatkan kondisi fisik agar mampu menunaikan kewajiban beribadah kepada Tuhan dengan baik. Jadi tujuan makan yang disebutkan di atas bukanlah untuk mencari kenikmatan semata, sehingga makan tersebut bukan merupakan tujuan hidup melainkan hanya sekedar alat untuk mempertahankan kehidupan dalam menjalankan misi kemansiaan dengan hamba Allah yang penuh pengabdian.

Demikian pula halnya keinginan untuk bersenggama; hal ini diciptakan menurut Al-Ghazali adalah untuk menggerakan keinginan atau nafsu senggama yang bertujuan untuk mempertahankan eksistensi manusia di muka bumi. Dengan demikian sepasang manusia yang beriman melangsungkan perkawinan adalah karena menginginkan keturunan dan membentengi nafsu, bukan bertujuan untuk bersenangsenang. ${ }^{42}$

Selanjutnya menurut Al-Ghazali ada dua hikmah yang dapat diambil dari syahwat alat kelamin dan syahwat perut, yaitu:

1. Menjadikan kelangsungan jenis manusia dengan makan dan pembibitan, karena keduanya

\footnotetext{
${ }^{42}$ Ibid, hlm. 99.
} 
memang diperlukan di alam wujud ini sesuai dengan sunatullah, dan dengan kehendak-Nya yang azali yang tiada pergantian dan perpindahan.

2. Mendorong umat manusia untuk mencapai kebahagiaan akhirat, sebab selama mereka tidak merasakan kelezatan duniawi dan kepedihannya, maka mereka tidak akan senang dan menginginkan surge, dan tidak takut neraka, dan seandainya mereka dijanjikan dengan adanya kenikmatan yang belum dilihat mata, belum didengar telinga dan belum terlintas di hati manusia, tentulah hal itu semua tidak terkesan dalam hati mereka. ${ }^{43}$

Dibanding dengan pokok keutamaan akhlak sebelumnya, al-iffat justru memiliki cabang dan cenderung lebih banyak. Al-Ghazali menyebutkan cabang-cabang $A l$-'iffat ini dalam tiga buah karyanya antara lain cabangcabang tersebut ialah $^{44}$ : 1) Al-Haya" (pertengahan antara tidak malu dan feminis (Al-Khunusat).

Al-Khajal (terlalu malu), 2) AlMusamahat (kesediaan melepaskan haknya dengan sukarela), 3) Al-Sabr (kemampuan jiwa melawan nafsu dan menjaganya dari kelezatan yang berakibat buruk), 4) Al-Sakha' (suka memberi sedekah dan menjauhkan dari memperoleh sesuatu yang bukan pada tempatnya), 5) Husn Al-Taqdir (seimbang dalam membelanjakan harta), 6) Al-Damasat, yaitu kondisi jiwa $A l$ Syahwaniyat yang baik dalam merindukan sesuatu yang sangat diinginkan), 6) Al-Intizam (kondisi jiwa yang mendorong untuk mengukur diri dalam membelanjakan harta), 7) Husn

${ }^{43}$ Ibid, lihat juga dalam Ihya, Jilid III, pada bagian. Kasr al-syahwatain. Op-Cit., hlm. 77104

${ }^{44}$ Ibid, Jus III, hlm. 53, “kitab al-Arba'in, hlm. 266. Mizan al- 'Amal’. hlm. 280283.
al-Hai'at (cinta kepada perhiasan yang wajib namun tidak sampai tergila-gila), 8) Al-Qona'at (Kemampuan mengatur kehidupan yang baik tanpa cela), 9) $\mathrm{Al}$ $H u d u$ (Ketenangan jiwa lantaran memperoleh kenikmatan yang baik), 10 Al-Wara' yaitu menghiasi jiwa dengan perbautan yang baik, 11) Al-Thalaqat atau Lathafat, yaitu bergurau yang sopan tidak keterlaluan,.12) Al-Zharf, yaitu pandai menempatkan diri, 13) AlMusa'adat, yaitu menghindari Perselisihan), 14) Al-Tasakhkhut, yaitu pertengahan antara dengki dan gembira atas kedudukan orang lain, 15) AlInbisath, yaitu merasa Senang).

Manusia yang dapat memelihara kehormatan diri atau pensucian dirinya dari hal-hal yang tidak baik, maka ia akan menumbuhkan sifat yang baik dari dalam dirinya. Seperti : sifat pemurah, memiliki rasa malu, sabar yang tiada batas, pemaaf, dan selalu menerima anugrah Allah Swt, memiliki sifat ramah, suka membantu atau menolong orang lain, daemawan dan tidak tamak terhadap harat ${ }^{45}$.

Selanjutnya, sifat al-Iffah juga tidak dibolehkan dalam keadaan yang berlebihan atau pun sebaliknya dalam kekuranga, hal itu, akan memunculkansifat yang negative. Dan akan muncul pada diri seseorang sifatsifat kebalikan dari yang baik, seperti, boros, sombong, riya, haus harta dan lain sebagainya. Maka, jika diperhatikan secara umum, penulis berpendapat, bahwa cabang-cabang dari sifat al-Iffah yang dikemukakan oleh Abu Hamid Muhammad bin Muhammad Al-Ghazali amat sangat mengutamakan keselamatan jiwa untuk menghasilkan perbuatan yang baik, dan hal itu merupakan ciri-ciri khusus dari konsep akhlak.

45 Al-Ghazali. Ihya Ulum al-Din. diterjemahkan Mohammad Zuhri dkk, hlm. 


\section{Pembahasan}

Dalam kerangka membersihkan jiwa, teori yang dikemukakan AlGhazali bersumber dari al-Qur'an. Islam itu sendiri memang sangat menganjurkan kepada manusia untuk selalu menjaga kesucian jiwa untuk ketenangan pada dirinya, dan sangat menganjurkan untuk mempersenjatai jiwa dengan berdzikir kepada Allah, sholat, memberi satu sama lain, serta selalu meminta perlindungan kepada Allah dari segala godaan syetan yang terkutuk. Dengan demikian, sangat beruntunglah bagi hamba Allah Swt, yang selalu mensucikan dirinya, dan sebaliknya, amat sangat merugi bagi hamba-Nya yang mengotori jiwanya. Sebagai mana Allah berfirman dalam alQur'an surat Al-Syams ayat 9-10.

Suatu kondisi bagi tiga macam kekuatan tersebut berada secara teratur dan sesuai dengan ketertiban yang seharusnya, maka itu disebut adil atau keseimbangan. Maka adil itu bukanlah dari sebagian keutamaan melainkan sebuah nama dari sejumlah keutamaan ${ }^{46}$. Perumpamaannya, jika ada seorang pemimpin serta pengikutnya sama-sama menerapkan ketertiban atau kedisiplinan dalam diri mereka masing-masing, semua pengikutnya akan memiliki sifat yang patuh pula kepada pemimpinnya dan mempunyai pasukan yang loyal serta taat terhadap aturan-aturan hukum yang berlaku. Maka akan dipastikan bahwa keadilan dalam sebuah negara akan dengan mudah dapat ditegakkan.

Namun jika prinsip tersebut tidak berjalan secara holistic, karena yang menjalankan peraturan hanya sebagiannya saja, serta pengikutnya tidak taat terhadap pemimpinnya, maka stabilitas, keadilan akan sulit untuk diwujudkan. Jadi, keadilan

${ }^{46}$ Al-Ghazali. Mizal al- 'Amal. M. Ali chasan Umar. hlm. 99.
(Keseimbangan) merupakan prinsip utama dalam ajaran akhlak. Keseimbangan atau keadilan dalam budi pekerti tentu akan dapat menimbulkan persamaan hak dan keadilan dalam pergaulan masyarakat, sehingga tidak aka nada manusia yang merasa tidak mendapatkan haknya setelah memenuhi kewajibannya. Maka pada setiap keadaan, keadilan merupakan cabang dari pada keadilan budi pekerti.

Al-Ghazali berpendapat mengenai keadilan dengan sebuah ketertiban yang disenangi, baik dalam berprilaku atau berbudi pekerti, hakhak pergaulan masyarakat, dan dalam unsur-unsur penegak kestabilan negara ${ }^{47}$. Keadilan dalam sebuah oergaulan di masyarkat adalah berada di antara kehinaan rugi dan merugikan, yaitu mengambil segala sesuatu yang harus diambil dan memberikan segala sesuatu yang harus diberikan.

Selanjutnya, menurut Al-Ghazali, bahwa segala sesuatu yang akan diperlukan hendaknya di tempatkan pada tempatnya. Ia juga mengatakan bahwa keadilan itu tidak diselubungi dengan dua kehinaan, namun harus diselubungi oleh kebalikan dari penyelewengan yang merupakan keadilan, karena antara keadilan dan adil, dan antara ketertiban dan tertib itu tidak ada pertengahan ${ }^{48}$.

Menurut Al-Ghazali, keadilan itu tidak memiliki ekstrim kelebihan dan ekstrim kekurangan. Keadilan hanya memiliki satu lawan makna, yakni ketidak adilan (al-Jaur), alasannya, karena tidak ada pertengahan antara keteraturan atau rapih dan ketidakteraturan atau ketidakrapihan ${ }^{49}$. Keadilan tidak mempunyai dua ujung, apa bila ia hilang, maka hilanglah kedua

\footnotetext{
${ }^{47}$ Ibid,

${ }^{48}$ Ibid, hlm. 100

${ }^{49}$ Al-Ghazali. Mizal al- 'Amal. hlm. 273.
} 
ujung tersebut, yaitu lebih dan kurang, tetapi yang ada hanyalah satu lawan dan satu penyeimbang, yaitu penyelewengan dan ketidak-adilan ${ }^{50}$.

Pokok-pokok keutamaan akhlak ini, yaitu al-Hikmah (kebijaksanaan), alSyaja'ah (Keberanian), al-Iffah (menjaga kehormatan diri) dan al-'Adl (Keadilan), menurut Al-Ghazali merupakan sumber dari akhlak yang baik (Akhlak al-Karimah), dan jika ada dalam bentuk-bentuk yang lain, maka hal itu hanya merupakan cabang dari ke empat jenis akhlak di atas. Dan Al-Ghazali berpendapat dalam kitabnya Ihya Ulum alDin, bahwa tidak ada yang memiliki akhlak yang sempurna, di mana semua kekuatan Ilmu, kekuatan emosi, kekuatan syahwat dan kekuatan adil di antara tiga kekuatan tersebut seimbang kecuali Rasulullah Saw, dan hal ini berbeda dengan Abu Bakar ar-Razi. Menurutnya, al fadhîlah -yang dimaksud al fadhîlah di sini adalah ishlâhu akhlâqin nafs 'an tharîqi ittibâ'il 'aqli wa qam'il hawâ wa tarkisy syahawât- tidak bisa diraih dengan sempurna kecuali oleh lelaki filosof yang utama, lelaki filosof yang sempurna itu adalah Plato $^{51}$.

Manusia saat ini, setelah masa Rasulallah Saw, berbeda-beda tingkatnya, mulai dari faham yang berbeda sampai pada pengamalan terhadap ajaran akhlak yang baik, terutama pada pengamalan ajaran pokok keutamaan akhlak yang diajarkan AlGhazali. Menurut penulis, pencapaian akhlak yang baik yang di ajarkan oleh Imam Al-Ghazali mampu dilaksanakan oleh setiap manusia, jika ia berusaha sepenuh hati, diusahakan lahir dan batin,

${ }^{50}$ M. Abdul Majid. Bimbingan Mencapai Ketenangan Jiwa. hlm. 44.

$51 \quad$ http://www.oaseimani.com/konsepakhlak-perspektif-Al-Ghazali.html diambil pada sabtu, 26 oktober 2013 pukul 10:10 WIB maka ia pun akan mencapai akhlak yang baik dan mencapai kemuliaan yang tinggi derajatnya sampai pada setingkat malaikat yang bisa terhindar dari noda dan dosa, namun sebaliknya, manusia yang tidak mempunyai tekad yang kuat untuk membersihkan diri, menjaga kehormatan dirinya, menghumbar hawa nafsunya serta tidak menghindari diri dari yang haram. Maka manusia itu pun bisa lebih rendah derajatnya dari pada binatang.

Menurut

Al-Ghazali

manusia yang berusaha untuk menggabungkan kesempurnaan akhlak tersebut, dari ke empat prinsip akhlak yang telah disebutkan, maka dia berhak menduduki derajat malaikat yang mulia di antara para makhluk yang lainnya. Semua makhluk akan merujuk kepadanya, dan mengikuti jejak-jejaknya dalam setiap perbuatan. Dan sebaliknya, setiap manusia yang memiliki sifat kebalikannya, maka ia berhak tidak lagi menyandang status sebagai hamba di hadapan Allah. Karena, ia telah dekat dengan syetan terkutuk yang menjauhkan manusia dari sisi Allah Swt., oleh karena itu, seharusnya sifat dan prilaku yang semacam itu harus dijauhkan dan selalu berusaha menjalankan sifat yang pertama yang akan menjadikan manusia akan sederajat seperti malaikat. Karena itu, Rasulallah Saw, tidak diutus kecuali untuk menyempurnakan akhlak manusia sebagai mana pernah di sabdakan oleh Rasulallah Saw bersabda, "Sesungguhnya aku diutus untuk meyempurnakan akhlak yang baik" (HR. Imam Malik).

Dan al-Qur'an pun telah memberikan isyarat kepada akhlakakhlak semacam itu. Berkaitan erat dengan sifat-sifat seorang mukmin, Allah Saw, telah berfirman : 
"Sesungguhnya orang-orang yang beriman itu hanyalah orangorang yang percaya (beriman) kepada Allah Swt, dan Rasul-Nya, kemudian mereka tidak ragu-ragu, serta mereka berjuang (berjihad) dengan harta, dan jiwa mereka pada jalan Allah. Mereka itulah orang-orang yang benar," (QS al-Hujarat [49] : 15).

Salah satu dari kekuatan dan keyakinan diri adalah mereka beriman kepada Allah Swt, dan Rasul-Nya, tanpa sikap ragu-ragu. Hal itu juga merupakan buah akal dan batas terakhir dari rangkaian hikmah (kebijaksanaan). berjuang dengan harta adalah sifat pemurah yang kembali kepada pengendalian atas kekuatan nafsu syahwat.

Sedangkan berjuang dengan jiwa, maka hal itu lebih sebagai keberanian yang kembali kepada penggunaan kekuatan ketegasan sesuai ketentuan akal dan batas kelurusan atau kebenaran. Semua itu sebagai isyarat bahwa sikap tegas mempunyai tempat tersediri, dan mempunyai sikap kasih sayang juga mempunyai tempat dan porsi yang khusus. Maka menurut Al-Ghazali, tidaklah disebut sempurna bersikap tegas di setiap tempat dan bersikap kasih sayang di setiap kondisi, jika menyalahi prinsip yang dibenarkan oleh Allah Swt.

Sebagian orang yang menuruti hawa nafsunya, dan dikalahkan sifat malas, maka menjadi berat baginya untuk berjuang, berlatih dan bekerja untuk mensucikan jiwa serta mendidik akhlak dengan yang baik. Kemudian orang yang seperti itu beranggapan atau menyangka bahwa akhlak yang dimiliki tidak tergambar sebagai sesuatu yang dapat berubah, karena ia beranggapan bahwa akhlak sebagai watak dasar (tabi'at) yang tidak mungkin dapat diubah, bersifat mabni (tetap tidak dapat dirubah ${ }^{188}$.

Alasan berfikiran semacam itu disandarkan pada dua perkara, yaitu :Pertama, Akhlak adalah suatu bentuk urusan batin, sebagaimana ciptaan diri atau fisik manusia lebih sebagai suatu bentuk yang lahir. Dengan kata lain, bahwa bentuk lahir itu tidak akan mampu untuk dirubah. Seperti orang yang bertumbuh tinggi tidak dapat dirumbah menjadi pendek, orang yang buruk rupanya tidak akan mungkin mampu dirumbah menjadi baik rupanya. Maka demikian pula dengan keburukan batin yang dianggap berlaku sama tidak dapat dirubah. Kedua, mereka berpendapat bahwa akhlak yang baik itu dapat dikondisikan dengan mengendalikan nafsu syahwat dan sifat mengelola marah $^{52}$.

Menurut Al-Ghazali, yang telah mencoba membuktikannya melalui riset (penelitian terpadu) atas hal itu, ia dengan tegas menolak atas pendapat manusia yang mengatakan bahwa akhlak tidak dapat berubah karena tabiat atau watak dasar. Oleh karena itu, Al-Ghazali beranggapan bahwa akhlak itu dapat diubah. Dan seandainya akhlak tidak mengalami perubahan, maka wasiat bijak, nasehat kebaikan, dan pendidikan tidak akan berarti apa-apa. Dan Rasulallah Saw, pun tidak akan pernah bersabda:

\section{"Perbaikilah akhlak kalian.",53}

Al-Ghazali melanjutkan, bagaimana hal itu dipungkiri pada akhlak manusia? Padahal, perubahan akhlak atau karakter pada binatang saja dapat kemungkinan terjadi. Pasalnya, binatang yang buas akan dapat diubah menjadi jinak, dan ia juga mencontohkan, bahwa seekor anjing yang rakus dalam urusan makan

\footnotetext{
${ }^{52} \mathrm{Ibid}, 195$.

${ }^{53} \mathrm{Ibid}$
} 
saja bisa dirubah menjadi menahan diri dan beretika. Dan begitu pula dengan hewan kuda liar yang dapat diubah dari sifat suka melawan menjadi penurut dan tunduk sesuai keinginan pengendalinya. Hal itu semua merupakan bentuk perubahan, dan merupakan perubahan yang bisa pula terjadi pada akhlak manusia ${ }^{54}$.

Menurut Al-Ghazali, pada hakikatnya manusia memang tidak akan bisa menghilangkan serta memaksa hilangnya nafsu emosi atau syahwat secara keseluruhan, manusia tidak akan mampu. Tetapi menurut AlGhazali manusia dapat mengekang dan mengendalikan keduanya dengan cara Riyadhah (melatih batin) dan mujahadah (mendekatkan diri pada Allah). Jadi, menurut Al-Ghazali, akhlak itu mengalami perubahan, dan perubahan itu dapat diperoleh melalui proses belajar atau selalu berusaha melatih jiwa untuk selalu melakukan perbuatan-perbuatan yang mendorong akhlak menjadi baik. Seperti akhlak dermawan, maka seseorang harus selalu melatih berderma dengan berbagi sesama mengeluarkan sebagian hartanya sehingga menjadi sebuah kebiasaan serta ringan setiap kali melakukannya ${ }^{55}$.

a. Manusia lalai. Ia tidak dapat membedakan antara yang hak (kebenaran) dan yang batil, yang bernilai kebaikan dan yang jelek, namun manusia seperti ini yang memiliki kecendrungan kembali dalam fitrahnya yang terbebas dari semua keyakinan, dan ia juga tidak mengikuti syahwat dengan sepenuhnya, tidak mengikuti kesenangan-kesenangan. Dan inilah manusia yang paling mudah

${ }_{55}^{54} \mathrm{Ibid}$,

55 Zaki Mubarak. 1408 H/1988 M. alAkhlak 'Inda Ghazali. Daarul Jil, Bairut, hlm. 156. untuk diobati. Ia hanya butuh seorang guru dan seorang petunjuk (mursyid) yang selalu mendorongnya kepada aktivitas mujahadah. Manusia semacam ini, perlahan tapi pasti akan menjadi baik (mulia) akhlaknya dalam waktu yang tidak terlalu lama.

b. Orang yang mengetahui buruknya suatu perkara tertentu. Akan tetapi, ia tidak membiasakan pada perbuatan yang baik, sekalipun ia telah mengetahui keutamaannya. Bahkan amalnya yang buruk dihiasi dengan seolah-olah berbuat baik. Kemudian ia selalu mengikuti hawa nafsunya dengan menyimpang dari fitrahnya yang benar. Artinya, dia selalu tunduk kepada syahwatnya dan menolak dari kebenaran rasionya, hal itu, karena di dalam dirinya telah dikuasai oleh syahwatnya dan tidak dikendalikan. Dan ia mengetahui, mengerti dan sekaligus menyadari penyimpangan dalam perbuatannya. Maka, menurut Al-Ghazali manusia semacam ini akan lebih sulit dari pada ciri manusia yang pertama, karena penyakitnya telah berlipat-lipat. Dan ia wajib melepaskan kebiasaan buruk yang telah mengakar dan melekat karena banyaknya ia pada membiasakan diri dalam kerusakan, dan harus mengarahkan jiwanya pada hal-hal yang berlawanan dengan kebiasaan buruknya.

c. Manusia yang telah terlanjru meyakini kepada akhlak yang buruk. Ia juga menyakini bahwa akhlak yang buruk itulah yang wajib dipandang sebagai sebuah kebaikan. Atau dengan kata lain, akhlak yang buruk baginya adalah kebenaran dan sesuatu yang berharaga bagi dirinya.

Dan ia pun telah terdidik dengan dengan akhlak yang buruk tersebut. Manusia yang semacam ini menurut AlGhazali, hamper-hampir mencegah pengobatan atas dirinya dan tidak bisa diharapkan kebaikan darinya kecuali 
sangat sedikit sekali yang bisa disembuhkan. Yang demikian itu karena berlipat-ganda sebab-sebab kesesatannya.

d. Manusia yang dalam pertumbuhannya berada di atas pemikiran yang batil/rusak, dan terdidik dalam mengamalkan keyakinannya tersebut. Orang semacam ini cendrung melihat keutamaan pada banyak keburukan, dan itu berpotensi menghancurkan jiwanya sendiri. Ia merasa bangga dengan apa yang telah ia

Kemudian,

Al-Ghazali menyimpulkan bahwa tipe orang yang pertama dari pembagian ini adalah orang yang tidak berilmu saja atau orang yang bodoh. Sedangkan tipe yang kedua, mereka adalah orang yang tidak berilmu dan juga tersesat. Tipe orang yang ketiga adalah orang yang tidak berilmu, tersesat, dan gemar berbuat kefasika/keburukan (fasik). Sedangkan tipe orang yang keempat adalah, orang yang tidak berilmu, tersesat, fasik dan jahat (Jahilun wa dhallun wa fasiqun wa syirrirun) $)^{56}$.

Al-Ghazali juga tidak sependapat dengan statemen yang menyatakan bahwa "selama manusia masih hidup, maka tidak akan terputus darinya perkara yang berkaitan dengan nafsu syahwat, sifat amarah, mencintai dunia, dan akhlak yang berbeda-beda atas ragam dari manusia" dan pendapat ini menurut Al-Ghazali disandarkan pada satu golongan yang mengira bahwa mujahadah adalah mengalahkan dan atau menundukan sifat-sifat ini secara keseluruhan. Pendapat seperti ini sangat jauh dari kebenaran makna mujahadah yang sebenarnya ${ }^{57}$.

Karena, nafsu syahwat menurut AlGhazali akan selalu ada pada manusia, dan untuk suatu kemanfaatan tertentu.

\footnotetext{
${ }^{56}$ Ibid, 196

${ }^{57} \mathrm{Ibid}$,
}

lakukan, dan mengira bahwa apa yang telah ia lakukan di dalam keburukan bisa mengangkat derajatnya dalam pandangan manusia. Hal ini menurut AlGhazali merupaka tingkatana yang palig sulit diobati. Perumpamaan orang semacam ini laksana melatih orang yang sudah tua, dan termasuk bagian dari siksaan adalah mendidik orang yang yang jahil. Atau seperti melatih singa liar agar beretika, dan mencuci sesuatu yang hitam pekat agar menjadi putih kembali.

Seperti nafsu makan, jika terputus pada manusia, maka manusia akan segera binasa. Sebagimana nafsu bersetubuh (penyaluran insting biologis), apabila hilang pada diri manusia, maka akan putus hirarki keturunan pada manusia. Maka yang dimaksudkan di sini ialah sifat pertengahan, kemampuan kendali, tidak tahawwur (sembrono), tidak berlebih-lebih, dan tidak pula terlalu kurang. Secara garis besar, menurut AlGhazali, jika di dalam diri manusia terdapat kekuatan, maka dengan kekuatan yang tersedia itu manusia akan patuh pada arahan pemahaman akal yang dibentengi hikmah dan ilmu. Untuk bisa sampai kepada kebaikan akhlak yang telah didukung oleh lurusnya kekuatan akal dan sempurnanya hikmah. Menurut AlGhazali terdapat dua syarat yang mengiringinya, yaitu ${ }^{58}$ :

Syarat Pertama, akhlak yang baik dengan karunia Allah Swt, berupa sempurnanya fitrah (ciptaan pertama), di mana manusia itu pada mulanya diciptakan dan dilahirkan dengan sempurna akalnya dan berakhlak mulia. Menurut penulis, Al-Ghazali dalam memberikan syarat yang pertama ini dengan melihat awal penciptaan manusia yang suci dan bersih dari segala yang buruk. Manusia juga diciptakan dengan sebaikbaiknya bentuk ciptaan. Didukung

\footnotetext{
${ }^{58}$ Ibid, 204.
} 
pula dengan sifat spiritual individunya Al-Ghazali yang selalu menyandarkan segala sesuatu berasal dari Allah yang maha bijaksana dan cinta kepada perbuatan yang baik.

Syarat kedua, proses membentuk akhlak menjadi baik yakni dengan cara selalu berusaha melalui Mujahadah dan menjalani proses Riyadah nafs. Azas yang terpenting di dalam mujahadah (perjuangan) adalah mewujudkan keinginan. Artinya, ada dorongan jiwa dan qalbu secara bersama-sama dengan kuat untuk mengerjakan perbuatanperbuatan yang dikehendaki oleh akhlak. Siapa yang menginginkan akhlak yang pemurah, maka jalannya adalah memaksakan dan membiasakan pada dirinya untuk melakukan perbuatanperbuatan yang mengarah kepada sikap pemurah; seperti membelanjakan harta di jalan Allah Swt, dengan kata lain, ia harus menuntut, membiasakan dan mewajibkan dirinya untuk hal yang demikian itu. Selain itu, penulis menambahkan, bahwa ia juga harus berkeinginan kuat untuk meninggalkan segala nafsu syahwat yang akan membawanya kepada kenikmatan dunia yang berlebihan.

Al-Ghazali juga mengingatkan akan adanya ujian selama perjalanan mujahadah (perjuangan), oleh akrena itu, hendaknya bagi mereka yang dalam proses menuju akhlak yang baik denga jalan mujahadah untuk selalu bersabar dan terus menjalankannya dengan istiqomah/kontinu ${ }^{59}$. Karenanya, jika ia mampu bersabar dari segala ujian, maka kenikmatan surgalah yang nanti akan menjadi tempat tinggalnya. Sebagai mana Allah berfirman dalam al-Qur'an Surat al-Nazi' at ayat 40-41.

Maksud dari selalu mendorong jiwa untuk melakukan amalan yang dituntut oleh akhlak adalah untuk memperbaiki jiwa. ${ }^{60}$ Dan untuk memperbaiki jiwa ialah dengan menghilangkan berbagai kenistaan dan akhlak yang buruk, serta meraih keutamaan dan akhlak-akhlak yang baik, sebagaimana mengobati anggota badan yang terkena sakit, yakni dengan menghilangkan penyakit dan mngusahakan kesembuhannya.

\section{Selanjutnya,}

Al-Ghazali mengatakan, sebagimana tubuh manusia itu pada mulanya tidaklah dijadikan secara sempurna. Sesungguhnya ia menjadi sempurna dan kuat melaui proses pertumbuhan, pendidikan dan asupan makanan. Maka, begitu juga halnya pada kondisi jiwa, ia dijadikan dalam keadaan kurang, tetapi memiliki potensi untuk sampai pada kesempurnaan. Jiwa bisa sempurna dengan didikan, akhlak yang baik, dan asupan ilmu pengetahuan.

Sebagaimana halnya tubuh, jika ia sehat, maka hal itu menjadi tugas seorang dokter merancang aturan yang bisa menjaga kesehatan. Dan jika ia sakit, maka tugas dokter itu membuatnya sehat kembali. Oleh karena itu jiwa seseorang jika ia murni, bersih dan terdidik, maka hendaknya diusahakan terus untuk memeliharanya. Sebagaimana alnya penyakit, ia merusak kebaikan badan yang kemudian membawanya pada ondisi sakit. Ia harus diobati dengan cara melawan penyakitnya begitu juga penyakit hati seseorang obatnya adalah dengan apa yang menjadi lawannya. Misalnya penyakit bakhil, diobati dengan sikap kedermawanan. Penyakit sombong, diobati dengan merendahnya hati (sikap tawadhu). Penyakit rakus, maka diobati dengan menahan diri secara paksa dari sesuatu yang diinginkan syahwat.

\footnotetext{
${ }^{59}$ Ibid, hlm 219.
} 


$\begin{array}{cl}\text { Rasulullah } & \text { Saw juga } \\ \text { pernah berpesan } & \text {-sebagai }\end{array}$

bentuk penyambutan kepada para sahabat yang baru dating dari perang, "Selamat datang untuk kalian yang baru datang dari berperang 'jihad asghar' (peperangan yang kecil) kepada 'jihad akbar' (peperangan yang besar)". kemudian ada sahabat yang bertanya "Wahai Rosulullah, apa itu 'jihad akbar' (peperangan yang besar)?" rosulullah Saw. Menjawab, "jihad nafsi (berperang melawan hawa nafsu kalian sendiri)",61

Nabi Saw. Juga pernah bersabda, "Yang dinamakan pejuang sejati itu adalah orang yang berhasil mengendalikan hawa nafsunya untuk menuju sikap taat kepada Allah 'Azza wa jalla." 62

Dari itu, menurut Al-Ghazali, untuk mencapai akhlak yang baik ada beberapa metode yang diajukan yang di dalamnya pun tidak terlepas dari Mujahadah dan Riyadah nafs. Diantaranya :

Pertama, adanya kemauan yang kuat, sungguh-sungguh (Mujahadah) untuk selalu berlatih (riyadhah) secara istiqamah atau kontinu dan menahan diri untuk mendapatkan keutamaan dan sopan santun yang sebenarnya sesuai dengan keutamaan jiwa agar tidak memperturutkan nafau syhawat dan alGhadabiyah. Pasalnya, kedua sifat ini terkait erat dengan yang ada di dalam tubuh, maka salah satu latihan penahanan dirinya adalah dengan berpuasa $^{63}$.

Menurut penulis, model yang dimaksudkan ini adalah model

${ }^{61}$ Diriwayatkan oleh Imam al-Baihaqi,

${ }^{62}$ Diriwayatkan oleh Imam Al-Tirmidzi dalam kitab "Atsana-I", dan beliau menshahihkan statusnya. Diriwayatkan pula oleh Imam Ibnu Majah dari hadits Fadhalan ibn 'Ubaid ra.

${ }^{63}$ Al-Ghazali. Ihya Ulum al-Din. Jilid III, hlm. 56-57.
Pembiasaan, karena, proses pembiasaan itu pada mulanya harus di paksakan, sehingga, dari sifat yang tidak biasa menjadi sifat yang mengakar di dalam dirinya. Seperti sholat berjamaah, jika tidak dibiasakan dan tidak dipaksakan, maka jiwa akan selalu dikalahkan dengan nasfu yang kuat yaitu rasa malas untuk melakukannya.

Model seperti ini, menurut Ulil amri bisa dilihat di dalam al-qur'an dengan term " 'amilu shalihat" dan hal itu pun diungkapkan dalam alQur'an sebanyak 73 kali, dan bisa diterjemahkan dengan kalimat "mereka selalu melakukan amal kebaikan" atau membiasakan perbuatan yang baikbaik" ${ }^{\prime 64}$. Proses pembiasaan di dalam pembentukan akhlak yang baik sangat diperlukan, seperti selalu memulai pekerjaan yang baik dengan membaca "basmalah."

Dan jika dalam prktiknya

proses ini dikesampingkan, maka pendidikan akhlak yang baik, akan menjadi sia-sia dan hanya akan menjadi wacana yang tidak akan pernah terwujudkan. Model pembiasaan merupakan praktek dari meteri yang telah di sampaikan, tentunya memerlukan bimbingan dan pengawasan.

Kedua, menjadikan segala sesuatu baik pengetahuan atau pun pengalaman orang yang berada disekitarnya sebagai cermin untuk dirinya. Dan tidak hanyut dalam perbuatannya. Metode ini bisa juga dikatakan sebagai mawas diri yang berfungsi untuk perbaikan akhlak yang buruk dan mencapai akhlak yang terpuji.

Model kedua adalah mawas diri, menurut penulis penulis model ini bisa disamakan dengan 'Ibroh atau i'tibar. Dimana I'tibar itu merupakan suatu kondisi psikologis yang mengantarkan

${ }^{64}$ Ulil Amri Syafri. Pendidikan Krakter Berbasis al-Qur'an. hlm. 137. 
manusia menuju pengetahuan yang diamati dan dirujuk, dituju oleh suatu perkara yang dilihat, diselidiki, ditimbang-timbang, diukur dan ditetapkan oleh manusia menurut pertimbangan akalnya sehingga dia sampai pada suatu kesimpulan yang dapat menjadikan hatinya tenang, baik, sehingga mendorongnya untuk berperilaku sesuai akalnya yang logis dan sesuai dengan kondisi pada dirinya sendiri di dalam kehidupan di masyarakat.

Pengamatan disekitar lingkungan, dari apa yang dia lihat akan berdampak kepada prilakunya, maka peran akal sehat dan ilmu yang ia dapat sangat diperlukan untuk mencerna, menganalisa apakah hal itu perbuatan baik atau buruk. Jika baik, maka rasionalitas akan mendorong dirinya untuk berbuat baik pula.

Ketiga, Muhasabat al-Nafs (introsfeksi). Metode ini sangat penting untuk memperbaiki akhlak dengan mengetahui segala kekurangan yang terdapat di dalam dirinya. Al-Ghazali memberikan metode untuk manusia yang ingin mengetahui kekurangan dirinya, di antaranya $^{65}$ : Dengan berkumpul bersama seorang guru (syekh) yang pandai melihat kekurangan diri, sekaligus mendapat bimbingannya. Kemudian dengan cara mencari teman yang benar dan kuat dalam agamanya. Selanjutnya dengan melalui orang yang tidak senang dengannya (musuh), yang kemudian orang tersebut selalu mencari-cari kesalahan, kekurangan dan kelemahannya. Dan jarang sekali mencari kelebihan dan keutamaanyaa. Dan yang terakhir, hendaknya ia selalu berkumpul kepada orang yang beriman. Karena sesungguhnya orang mukmin itu adalah sebagai cermin orang mukmin yang lainnya, dan saling menginggatkan satu sama lainnya.

Menurut hemat penulis, untuk model yang ketiga ini tidak akan sempurna jika tdak ada keteladanan (Qudwah), pasalanya, sebagai mana menurut Al-Ghazali, bahwa untuk mengetahaui kekurangan dirinya harus selalu dekat dengan orang yang dipandang lebih baik darinya, dan untuk selalu dimintai nasihat, bimbingan dan pengarahan, hal ini hanya bisa dilakukan oleh orang yang dianggap lebih tinggi kedudukannya. Seperti guru di dalam lingkungan pendidikan, orang tua di dalam lingkungan keluarga, pimpinan di dalam suatu komunitas atau kelompok.

Peran-peran mereka itu yang kemudian menjadi acuan dalam prilaku seseorang. Dan hal ini juga, seperti yang dilakukan oleh para sahabat nabi Saw. Yaitu selalu dekat dengan nabi untuk dimintai nasehat, bimbingan dan selalu di lihat sikap dan prilakunya nabi Saw. Bahkan dijelaskan juga, bahwa salah satu obat hati adalah selalu berkumpul dengan orang-orang sholeh, orang-orang yang prilakunya baik.

Keempat, metode ini menurut penulis yang dapat disimpulkan dari uraian Al-Ghazali adalah metode lawan dari kebalikannya, seperti penyebab akhlak yang buruk harus dilawan dengan perbuatan yang baik disertai dengan ilmu dan hikmah. Ilmu dan hikmah bisa disebut pengobatan secara teoritis, sedangkan perbuatan yang baik adalah pengobatan secara praktis. Dalam menerapkan proses yang ke empat ini bukan hal yang mudah, pasalnya, manusia harus membenturkan keinginan hawa nafsu yang biasa dilakukan dengan cara mengekangnya dan melakukan perbuatan-perbuatan yang tidak menuruti hawa nafsu.

\footnotetext{
${ }^{65}$ Ibid, hlm. 63.
} 
Metode keempat ini melawan perbuatan yang selalu menuruti hawa nafsu, maka, menurut penulis peoses ini bisa juga disebut jalan tengah. Artinya, Al-Ghazali menjelaskan, jika manusia ingin mengetahui makna pertengahan, maka perhatikanlah kepada perbuatan yang seharusnya oleh akhlak bisa dijauhi. Jika oleh perbuatan yang dimaksud lebih mudah bagi manusia untuk melaksanakannya, dan lebih nyaman daripada perbuatan yang menjadi lawannya, maka yang lebih kuat pada sisi manusia adalah akhlak yang mewajibkan pada perbuatan tersebut. Misalnya, menahannahan harta yang dimiliki lebih mudah dan enak daripada membeikan harta itu untuk jalan Allah Swt, yaitu memberikan harta kepada yang berhak, maka ketahuilah bahwa yang lebih kuat pada diri manusia tersebut adalah sifat kikir. Oleh karena itu, sempurnakanlah di dalam menginfakkan harta kepada yang berhak menerimanya ${ }^{66}$.

Jika menginfakan harta kepada ornga yang tidak berhak menerimanya, dan itu menjadikan rasa yang nyaman pada diri manusia. Dan lebih ringan daripada menahankannya dengan benar, maka itu pun lebih kuat pada sifat yang berlebihan atau boros pada diri manusia. Maka kembalilah kepada cara pertengahan, yakni kepada membiasakan sifat menahan diri agar tidak berlebihan.

Pada hakekatnya, pelaksanaan menuju akhlak yang baik berada pada keseriusan manusia itu sendiri, maka mujahadahnya kepada pengekangan hawa nafsu merupakan riyadah nafs menuju akhlak yang baik. Karena penyembuhan akhlak yang buruk terjadi melalui proses yang bersifat teoritis dan praktis secara bersamaan. Teoritis berarti

66 Al-Ghazali, "Ihya Ulum al-Din", terjemah, Ibnu Ibrahim Ba'adillah, hlm, 224. ${ }^{213}$ Ibid, hlm. 262. mempelajari, menghayatai dan menganalisa akhlak yang buruk, dan secara praktis itu merubah akhlak yang buruk tersebut dengan akhlak yang berlawanan.

Kelima, metode yang dijelaskan AlGhazali adalah berkaitan dengan lingkungan, ia menjelaskan, "hendaknya anak selalu disibukan di madrasah", karena madrasah di dalamnya terdapat pembelajaran, seperti belajar al-Qur'an, hadits-hadits $^{213}$. Di mana hadits tersebut banyak yang mengandung cerita-cerita, dan riwayat-riwayat serta tingkah laku orangorang yang baik, hal itu dimaksudkan agar anak bisa mengikuti tingkah lakunya dan tertanam di dalam jiwa anak rasa cinta kepada orang yang shaleh $^{67}$.

Di sini penulis berpendapat, bahwa di dalam lingkunga yang baik akan terdapat cerita yang baik, dan di dalam sebuah kisah-kisah, tersimpan hikmah yang dapat di ambil. Bahkan al-Qur'an sendiri banyak sekali yang bermuatan dengan kisah orang-orang terdahulu, begitu juga dengan hadits nabi, banyak pula yang menceritakan kisah orangorang yang baik dan yang jelek. Ada yang baik untuk diikuti da nada pula yang tidak patut untuk diikuti. Contoh kisah yang dapat diikuti adalah kesabaran nabi Ibrahim as dan nabi Ismail as dalam menjalankan perintah Allah Swt, pristiwa ini ditulis pada alQur'an surah as-Shaffat ayat 101-107.

Sedangkan kisah di dalam al-Qur'an yang tidak patut diikuti seperti kecongkakan kaum nabi Nuh as, yang kemudian datang malapetaka bagi kaumnya berupa banjir besar (great flood $)^{68}$, kisah ini pun diceritakan di

${ }^{67}$ Ibid

${ }^{68}$ Prof. Dr. Ace Partadireja. 1999. AlQur'an; Mukjizat Karomah Maunah dan Hukum Evolusi Spiritual. Yogyakarta: Dana Bhakti Prima Yasa. hlm. 
dalam al-Qur'an surah Hud ayat 48-48. Kemudian kesombongan kaum nabi Hud as, tanpa alasan yang benar, dan merasa kaumnya itu lebih kuat, perkasa dari pada apa yang di sembah nabi Hud as. Dan kemudian Allah S.W.A. kirim angina sorsor selam delapan hari tujuh malam secara terus menerus di Hadralmaut Yaman. Kisah ini direkam pada surah al-Fushshilat ayat 15-16, alHaaqah ayat 6-8, dan al-Fajr ayat 6-8.

Contoh-contoh tesebut baik untuk diceritakan kepada anak-anak agar bisa meniru yang baik dan meninggalkan kisah yang kurang baik. Masa kanakkanak sangat baik untuk pendidikan dan muatan ilmu pengetahuan, Al-Ghazali menyarankan untuk selalu menjaganya. Karena sesungguhnya anak itu pada naluri kejadiannya, anak juga diciptakan dalam keadaan yang labil, sehingga bisa menerima kebaikan dan bisa menerima kejahatan. Maka kedua orangtuanyalah yang membawa atau menjadikan anak itu baik atau buruk, condong kepada yang benar atau salah.

Rasulullah Saw, pernah bersabda, "Setiap anak yang dilahirkan itu adalah dalam keadaan suci, maka kedua orangtuanyalah yang menjadikannya Yahudi, atau Nasrani atau Majusi ${ }^{69}$. (Muttafaqun 'Alaih)

Konsep menuju perbaikan akhlak menurut Al-Ghazali memang sangat menitik beratkan pada manusia dan yang lebih mudah adalah terhadap anak usia dini. Perkembangan dan daya ingat anak terutama sejak usia dini harus dimanfaatkan orang tua dan juga guru sebagai pendidik dengan pembiasaan yang baik, hal ini juga sejalan dengan sebuah pribahasa yang mengatakan "Belajar diwaktu kecil bagai mengukir di atas batu, dan belajar diwaktu dewasa

${ }^{69}$ Diriwayatkan oleh Imam Bukhari dan Imam Muslim, dari hadits Abu Hurairah ra. (waktu tua) bagai mengukir di atas air" 70 .

Dari beberapa metode proses akhlak di atas, semua bertujuan untuk menyempurnakan bentuk jiwa agar menjadi lebih baik proses tersebut antara lain ; Mujahadah dan Riyadhah. Kesungguhan manusia untuk berubah haruslah kuat dan dengan tekad yang benar, disertai pula pelatihan (riyadhah al-Nafs) untuk tidak menuruti hawa nafsu, mengekang agar tidak melampaui batas. Pelatihan tersebut harus dilakukan dengan proses berikutnya yaitu Istiqomah (kontiu) atau dengan kata lain adalah pembiasaan untuk selalu berbuat baik ('Amal Shaleh).

Selain itu, mawas diri juga menjadi penting dalam membentuk akhlak yang baik. Menjadikan sesuatu yang terdapat pada orang lain sebagai cermin bagi dirinya, dengan cara ini diharapkan seseorang tidak hanyut ke dalam perbuatan yang tidak karena melihat dan menganalisa dari ketidak baikan orang lain. Dan metode tersebut juga selalu berkaitan dengan Muhasabat al-Nafs yakni introsfeksi. Metode ini mengandung pengertian sebuah kesadaran untuk mencari sendiri cacat atau aib pribadi, artinya, lebih baik sibuk memperhatikan kekurangan atau kesalah diri sendiri dari pada mengurus kesalahan orang lain.

Proses introsfeksi akan lebih sempurna jika terdapat Qudwah (keteladanan) untuk selalu mengingatkan akan kebaikan dan untuk menjauhi perbuatan yang jelek. Dengan selalu dekat kepada orang yang baik, maka diharapkan juga dapat mengikuti jejaknya. Maka dari itu, dalam memilih

${ }^{70}$ Fathiyah Hasan Sulaiman. 1986. Konsep Pendidikan Al-Ghazali. Alih bahasa Ahmad Hakim dan M. Imam Aziz. Jakarta : P3M. hlm. 63. 
teman dekat atau guru sebagai pembimbing tidak sembarangan, melainkan dengan kehati-hatian.

Metode salanjutnya adalah lawan dari kebalikan. Penulis berpendapat metode ini dengan opposisi, artinya, segala macam penyebab akhlak yang buruk harus dilawan dengan kebaikan, dan kebaikan lebih sempurna jika mendapat ilmu dan hikmah. Hal ini bukan pekerjaan yang ringan, sebab melawan keinginan hawa nafsu merupakan pekerjaan yang berat tantangannya.

Selanjutnya adalah lingkungan yang baik, di dalam lingkungan yang baik akan terdapat cerita yang baik, dan

Hakikat manusia di muka bumi ini adalah sebagai Khalifah, makhluk yang paling mulia dan sempurna yang Allah ciptakan. Penciptaan manusia bukan tanpa missi yang jelas dan main-main, untuk memelihara keberadaan dan keselamatan bumi dan yang Nampak di dalamnya. Hal itu pula, Allah lengkapi manusia dengan akal dan nafsu.

Akal dianggap penyeimbang nafsu yang berlebihan, dan tidak lengkap keberadaannya tanpa ada ilmu dan hikmah. Bimbingan ilmu terhadap akal diperlukan agar memunculkan kelakukan yang baik, akhlak yang mulia dan terpuji. Sehingga manusia menjadi makhluk yang tidak sia-sia penciptaannya.

Sebagai mana telah diuraikan sebelumnya pada pembahasan pokok, yakni pemahasan akhlak dalam perspektif al-Ghazali, materi dan metode akhlak al-Ghazali sangatlah penting dan mendasar pada proses pendidikan saat ini. Selanjutnya pada bab ini, penulis akan menyimpulkan semua yang menjadi pokok permasalahan, dan terjawab semua apa yang penulis amati, telaah dan analisa. diharapkan menularkan kepada jiwa agar menjadi lebih baik. Metode-metode ini yang diharapkan dapat menjadikan jiwa manusia pada jalan yang benar, akhlak yang terpuji dan mulia, sehingga manusia mendapatkan kebahagian baik di dunia lebihlebih di akhirat.

Dengan demikian, menurut penulis, konsep akhlak yang telah dijelaskan oleh Imam al-Ghazali, jika dilihat dari pendekatan dan juga metode, pendidikan akhlak yang dijelaskan cendrung bersifat praktis, dan diterapkan langsung dalam kehidupan sehari-hari dengan cara spontan.

\section{E. KESIMPULAN}

Pertama; pengertian akhlak menurut al-Ghazali adalah: "Suatu ibarat atau ungkapan tentang kondisi yang menetap di dalam jiwa, dari keadaan dalam jiwa itu kemudian muncul perbuatanperbuatan dengan mudah, tanpa memerlukan pemikiran maupun penelitian". Jadi, apabila aplikasi dari kondisi tersebut muncul perbuatanperbuatan yang baik dan terpuji secara akal dan syara', maka kondisi tersebut disebut sebagai akhlak yang baik. Sedangkan apabila perbuatan-perbuatan yang muncul dari kondisi yang dimaksud adalah sesuatu yang berdampak buruk, maka keadaan yang menjadi tempat munculnya perbuatan-perbuatan itu disebut sebagai akhlak yang buruk .

Pendapat ini sejalan dengan pengertian akhlak Imam Ibnu miskawaih (320-450), yaitu, sama-sama merupakan sikap batin yang mampu mendorong secara spontan untuk melahirkan semua perbuatan yang bernilai baik. Perbedaan yang penulis amati dari segi pendekatannya. Menurut Ibn Miskawaih lebih cendrung bersifat teoritis, sedangkan pendekatan yang dilakukan oleh al-Ghazali baik materi maupun 
metodenya cendrung bersifat praktis yang diterapkan langsung dalam kehidupan sehari-hari secara spontan.

Sedangkan hakikat akhlak menurut al-Ghazali adalah seperti kondisi jiwa dan bentuknya yang batin. Sebagaimana sempurnya bentuk lahir secara mutlak yang kemudian menjadi tidak sempurna dengan indahnya keberadaan dua mata saja, tanpa hidung, mulut dan pipi, tetapi kebagusan semuanya harus ada agar kebagusan dhahir menjadi sempurna. Maka, demikian pula dalam urusan batiniah (jiwa), ada empat unsur yang harus baik semua, sehingga kebagusan akhlak menjadi sempurna. Apabila kebagusan empat unsur ini seimbang dan setara serta sesuai maka kebagusan akhlak bisa di dapatkan dan niscaya akan mencapai kemuliaannya. Diantara empat unsur tersebut adalah: kekuatan ilmu, kekuatan emosi, kekuatan syahwat, dan kekuatan adil diantara tiga kekuatan tersebut .

\section{Landasan dan Tujuan}

Menurut al-Ghazalai tujuan akhlak yang telah diuraikannya adalah terbentuknya suatu sikap batin yang mendorong munculnya keutamaan jiwa, dan biasa disebut al-Ghazali dengan al$\mathrm{Sa}$ 'adat al-Haqiqiyat (kebahagiaan yang hakiki). Dikatakan sebagai kebahagiaan yang hakiki karena, karena akhlak merupakan pusat yang menjadi dasar penilaian keutamaan pada manusia. Dan keuatamaan jiwa menjadi salah satu jalan ketenangan batin manusia sehingga tercapai tujuan hidup yang sebenarnya. kemudian yang menjadi landasan atau konsep akhlak yang dipaparkan alGhazali adalah al-Quran dan al-Hadist.

Tujuan selanjutnya dari pendidikan akhlak adalah proses manusia untuk mendekatkan diri kepada Allah Swt, selain itu juga sebagai tujuan akhir yang akan dicapai oleh manusia.
Membersihkan diri (tazkiyatun anNafs), terbiasa selalu berbuat kebaikan dengan akhlak yang kaamil (sempurna), ma'rifah, dengan kata lain ia selalu mendekatkan diri kepada Allah Swt, untuk mendapatkan kebahagiaan dan ketenangan di dunia dan kahirat.

\section{Pembagian Akhlak}

Merujuk dari definisi, dasar dan tujuan di atas, selanjutnya al-Ghazali membagi akhlak kepada dua macam, yaitu; akhlak yang baik (al-Khuluq alHasan) dan akhlak yang buruk (alKhuluq as-Sayyi').

\section{Metode Pembentukan Akhlak}

Al-Ghazali menjelaskan cara mendapatkan akhlak yang baik, diantaranya; pertama dengan Mujahadah dan Riyadhah, artinya, manusia dalam menuju kepada kebaikan harus memiliki tekad yang kuat. Kedua pembiasaan dengan istiqomah atau selalu melakukan amal shaleh. Ke tiga ialah mawas diri, menurut penulis metode ini lekat dengan ibroh atau I'tibar. Ke empat, Muhasabat al-Nafs atau dengan istilah lain introsfeksi, menyibukan diri dengan menilai kesalahan dan kekurangan dalam diri sendiri dan tidak sibuk dengan kesalahan orang lain. Kelima adalah oposisi, artinya lawan dari kebalikan, melawan segala keinginan nafsu yang berlebihan dengan perbuatan-perbuatan yang baik. Dan yang terakhir adalah selalu dalam lingkungan yang baik, pasalnya, di dalam lingkungan yang baik terdapat cerita atau kondisi yang baik, hal itu diharapkan agar anak selalu terbiasa pada kondisi yang baik, sehingga melekat dalam dirinya perbuatan yang baik. Konsep akhlak yang ditawarkan al-Ghazali ini diharapkan dapat meruntuhkan sifat sombong pada manusia. Dan bertujuan agar menjadi manusia yang bahagia di dunia dan di akhirat, dengan 
menjalankannya secara tepat,
mengaplikasikan dan mendalaminya

\section{DAFTAR PUSTAKA}

Abdullah, M. Amin. 2002. "Antara al Ghazali dan Kant : Filsafat Etika Islam”, Cet. I. Bandung: Mizan.

Ahmad, Zainal Abidin. 1975. "Riwayat Hidup Imam Al-Ghazali", Jakarta: Bulan Bintang.

Amin, Ahmad. 1983. "Etika, Ilmu Akhlak", cet III, (terj) K, H, Farid Ma'ruf dari, Al-Akhlak,Jakarta,Bulan Bintang.

Amin, Maswardi Muhammad. 2011. "Pendidikan Karakter Anak Bangsa", Jakarta ; Baduose Media Jakarta.

Asmara, AS. 1994. "Pengantar Tsawuf”. PT. Raja Grafindo, Persada 1992. "Pengantar Studi Akhlak”, Jakarta: Rajawali Pers

Asnawi, al. 1378. 'Thabaqotu alSyafi'iyah", Tahqiq Abdullah al-Jaburi, Baghdad : Matba'ah Isa al-Babi alHalabi, Jilid VI.

Assegaf, Abd Rahman. 2005. "Studi Islam Kontekstual; Elaborasi Paradigma Baru Muslim Kaffah", Yogyakarta: Gema Media.

Baidawi, Abdurrahman. 1924. "Madzahib Al-Islamiyah", Beirut: Dar Al-'Ilmi wa Al-Malayin.

Bagus, Lorens. 2002. "Kamus Filsafat", Jakarta: Gramedia Pustaka Utama

Bertens, K. 2002.“Etika”, Jakarta: Gramedia Pustaka Utama.

Daud, Anas Ismail Abu. 2004. "Dalil As-Sailin; Ensiklopedi Dakwah", Malang: Al-Qayyim. dalam setiap kehidupan sehari-hari.

Dewantara, Ki Hajar Dewantara. 1996. "Bagian Pertama Pendidikan", Yogyakarta: Taman Siswa

Direja, Ace Parta. 1999. "AlQur'an ; Mukjizat Karomah Maunah dan Hukum Evolusi Spiritual", Yogyakarta : Dana Bhakti Prima Yasa

Djamaluddin, 1988. "Kapita Selekta Pendidikan Islam”, Bandung : Pustaka Setia.

Dunya, Sulaiman. 1971. "AlHaqiqah fi Al-Nazhar Al-Ghazal" $i$, Mesir : Dar al-Ma'rifah, cet, III.

1947. "Al-Jaqiqah fi Nazar Al-Ghazali”, Kairo: Dar Al-Kutub Al-Arabiyah.

Farahidi, Abu Abdurrahman alKhalil bin Ahmad al, Tt., "Kitabul 'Ain", Tahqiq; Dr. Mahdi al-Makhzumi dan Dr. Ibrahim as Samirai, maktabah al-Hilal, Juz IV. Jilid 2.

Faris, Ibnu, "Maqayis al-Lughah",

Gazalba, Sidi. 2001. "Sistematika filsafat: Buku Keempat Pengantar Kepada Teori Nilai”, Jakarta: Bulan Bintang.

Ghazali, Abu Hamid Muhammad bin Muhammad Al. 1986. "Mizan alamal", Taqdim, Sulaiman sulaim alBawwab, Beirut: Daarul Hikmah.

1988, “Kitab al-Arba'in Fi

Usul al-Din”, Beirut : Dar al-Jil. 1991, “Ihya 'Ulum al-Din”, Beirut: Dar al Jil.

Ihya "Ulum al-Din", terjemahan Ibnu Ibrahim Ba'adillah.

Tt., "Al-Munqiz min $\mathrm{Al}$ Dhala", Tahqiq Jamil Shulaiba dan Kamil. 
Iyyad, Beirut: Dar Al-Andalus Tt, "Ihya Ulum al-Din”. Bairut : Darul Fikr, juz III.

Singgih, Gunarsa. 1999. "Psikologi Perkembangan”, Jakarta : Gunung Mulia.

Hamid, Abdul. 1974. "Al-Munqiz min Al-Dhalal Li Hujjat Al-Islam AlGhazali ma a abbas fi At-Tasawuf wa Dirasat an Al-Imam Al-Ghazali", Kairo: Dar Al-Kutub Al-Haditsah.

Hamka, 1993. "Tasawuf, Perkembnagan dan pemurnian", Pustaka Panjimas

Hasyim, Ahmad Umar. 2004. "Menjadi Muslim Kaffah ; Berdasarkan al-Qur'an dan Sunnah Nabi", terjemah Joko Suryanto, Yogyakarta: Mitra Pustaka.

Hasyimi, Abdul Mun'im al. 2009. "Akhlak Rasul menurut Imam Bukhari dan Muslim”, Jakarta : Gema Insani.

Helmy, Masdar, “Akhlak Nabi Muhammad SAW,keluhuran dan kemuliaannya",

Hitti, Philip K. 1970. "History of the Arabs", London: The Machmillen Presc.

Husaini, Adian. 2011. "Pendidikan Islam, Memebentuk Manusia Berkarakter dan Beradab", Jakarta: Komunitas Nuun.

Husaini, Adian,et, all. 2013. "Filsafat Ilmu Perspektif Barat dan Islam”, Jakarta: Gema Insani.

Jawad, Musthafa, "Ashr AlGhazali" dalam Muhrajan Al-Ghazali bi

Dimasyq "Abu Hamid Al-Ghazali fi zikr Al-Mu'awiyat l-Tasi'at li Miladihi", Kairo: Al-Majlis Al-A'la li ri'ayat AlFunun wa Al-Adab wa Al-Ulum AlIjtima'iyah, 1962.

Jurjani, Ali bin Muhammad bin Ali al, Tt, "At-Tarifat", tahqiq; Ibrahim albayari, Bairut : Darul Kitab al-Arabi, Juz I.

Khaldun, Ibnu. 2001. "Mukaddimah", terjemahan masturi Lc, dkk, Jakarta : Pustaka al-Kautsar.

Lickona, Thomas. 2012. "Educating For Character", trj. Juma Abdu Wamanguo, Mendidik untuk membentuk Karakter, Jakarta, Bumi Aksara.

Lubis, H. M. Arief. 1965. "Imam Al-Ghazali dan Folosof Barat", Cet. II, Jakarta: Bulan Bintang.

Ma'arif, Ahmad Syafi'I. 1997. "Islam Kekuatan Doktrin dan Kegamangan Ummat”, Yogyakarta: Pustaka Pelajar.

Maftuhah, Anna. 2005. dalam Tesis "Konsep Akhlak Ibnu Miskawaih" Pasca Sarjana Program Magister Agama Islam Universitas Ibn Khaldun Bogor.

Mahjuddin. 2010. “Akhlak Tasawuf II, Pencarian Ma'rifah bagi Sufi Klasik dan Penemuan Kebahagiaan Batin bagi Sufi Kontemporer", Jakarta: Kalam Mulia.

Mahmud, Abdul Halim, "Qadhiyah al-Tashauf al-Munqidz min al-Dhalal", Kairo: Dar al-Ma'rifah,

Majid, Abdul al-Aziz Abdul al, Tt. “Al-Tarbiyyah wa-Turuq Al-Tadris", juz I, Dar al-Ma'arif. Qairo.

Mishri, Muhammad bin Mukarram bin Manzur al-Afriqi al, "Lisanul 'Arabi”, Bairut : Daru Shadir, cet. I, Juz 10.

Miskawaih, Ibn. 1398. "Tahdzib alAkhlaq", tahqiq, syekh Hasan Tamir, Bairut, Dar Maktabat al-Hayat.

Mubarak, Zaki. 1924. "Al-Akhlak 'inda Al-Ghazali”, Kairo: Darul Kitab $\mathrm{Al}^{\prime}$ Arabi . 
Mubarak, Zaki. 1988. "Al-Akhlak 'Inda Ghazali”, cet, I, 1408 H/1988 M. Beirut: Daarul Jil.

Muhammad, Herry, dkk. 2006. "Tokoh-tokoh Islam Abad 20 yang berpengaruh”, Jakarta : Gema Insani.

Munawwir, Achmad Warson. 1997. “Al-Munawwir”, Yogyakarta : Pustaka Progresif.

Muslich, Mansur. 2011. "Pendidikan Krakter : menjawab Tantangan Krisis Multidimensional”, Jakarta; PT Bumi Aksar.

Musthofa, 1997. "Filsafat Islam". Pustaka Setia, Bandung : Mizan

Nadwy, Abu Al-Hasan Al. 1969. "Rizal Al-Fikry wa Al-Dakwah fi AlIslamiyah", Kuwait: Dar Al-Qalam.

Nata, Abuddin. 2012. "Akhlak Tasawuf”, Jakarta: Raja Wali Pers.

2001. "Pemikiran Para tokoh Pendidikan Islam”, Jakarta: Rajawali Pers.

Natsir, Mohammad. 2006. "Fiqhud Da'wah”, Media Dakwah, Jakarta, 2006, cet, XII.

Poerwadarminta, W.J.S. 1991. "Kamus Umum Bahasa Indonesia", Jakarta:,Balai Pustaka.

Rajab, Mansur Ali. 1961. "Taammulat, Fi-Falsafah al-Akhlaq", al-Injiliwi al-Misriyah, Qairo.

Ridajuddin FN. 2008. "Kehidupan Sufistik Versi Al-Ghazali, dan responnya terhadap dinamika perkembangan Tasawuf”, Jakarta : LPSI Jakarta

Samarqandi, Abullaits al. 2011. "Mutiara Hadit, Tanbihul Ghafilin;Peringatan Bagi yang Lupa", alih bahasa, Salim Bahreisy, Surabaya : Bina Ilmu, hlm. 834.
Sauri, Sofyan Sauri. 2011. "Filsafat dan Teosofat Akhlak", Bandung : Rizqi Press.

Selamat, Kasmuri, dan Ihsan Sanusi, "Akhlak Tasawuf, Upaya Meraih Kehalusan Budi dan Kedekatan Ilahi", Kalam Mulia, Jakarta.

Shihab, M. Quraish. 2010. "Tafsir al-Mishbah", Jakarta : Lentera Hati.

Sholeh, Q., dan A. Ahmad Dahlan. 2000. "Asbabunnuzul;, Latar Belakang turunnya Ayat-ayat al-Qur'an", Bandung, Diponogoro.

Siraj, Fuad Mahbub. 2012. "AlGhazali ; Pembela sejati Kemurnian Islam”, Jakarta: Dian Rakyat.

Sulaiman, Fathiyah Hasan, 1986, "Konsep Pendidikan Al-Ghazali", Alih bahasa Ahmad Hakim dan M. Imam Aziz. Jakarta : P3M.

Sutrisno, 2011. "Pembaharuan dan Pengembangan Pendidikan Islam, membentuk insan kamil yang sukses dan berkualitas", Yogyakarta: Fadilatama.

Suyuti, Jalaluddin al, Tt. "Al-jami'u Al-Saghir Fi-alhadith Al-Basyir AlNadhir", juz I, Beirut: Dar al-Fikr.

Syafri, Ulil Amri. 2012. "Pendidikan Krakter Berbasis alQur'an”, Jakarta : Rajawali Pers.

Syaifuddin, Fuad. 2011. "Bunga Rampai Pribahasa Arab”, Cet. I, Jakarta : Rene Asia Publika.

Tim Penyusun Kamus Pusat dan Pembiaan dan Pengembangan Bahasa Depdikbud, Kamus Besar Bahasa Indonesia, Balai Pustaka; Jakarta, 1994.

Zar, Sirajuddin. 2009. "Filsafat Islam; Filosof dan Filsafatnya”, Jakarta: Rajawali Pers.

Zubair, Achmad Charis,1980, Kuliah Etika, cet II, Jakarta: Rajawali Pers. 
http://blog.dianmas.com/2013/03/penger tian-pendidikan-karakter- menurut-paraahli.html. Pada Hari Sabtu, 28, September, 2013, Pukul 21:40 http://edukasi.kompasiana.com/2013/04/ 22/kurikulum-2013-dari-sisi-

pandang-uu-no20-th-2003-tentangsisdiknas-553630.html dilihat pada hari ahad tgl 8 bulan pkl 21;30 2013 http://www.oaseimani.com/konsep-
akhlak-perspektif-Al-Ghazali.html diambil pada sabtu, 26 oktober 2013 pukul 10:10

WIB https://www.facebook.com/Komunikasi AntarGuruIndonesia/posts/101512

10009741483 lihat juga Yasmadi,M.A, Modernisasi Pesantren, hlm, 3 di Lihat Pada hari ahad tgl 8 bln sept 2013. 
